NBER WORKING PAPER SERIES

\title{
LABOR SUPPLY AND THE VALUE OF NON-WORK TIME: EXPERIMENTAL ESTIMATES FROM THE FIELD
}

\author{
Alexandre Mas \\ Amanda Pallais \\ Working Paper 23906 \\ http://www.nber.org/papers/w23906 \\ NATIONAL BUREAU OF ECONOMIC RESEARCH \\ 1050 Massachusetts Avenue \\ Cambridge, MA 02138 \\ October 2017
}

We would like to thank Gabriel Chodorow-Reich, Jan Eckhout, Lawrence Katz, Bobby PakzadHurson, and seminar participants at Brown University and the University of Bonn for comments. We would also like to thank Jenna Anders, Stephanie Cheng, Kevin DeLuca, Jason Goldrosen, Disa Hynsjo, and Carl Lieberman for outstanding research assistance. Financial support from NSF CAREER Grant No. 1454476 is gratefully acknowledged. The project described in this paper relies on data from a survey administered by the Understanding America Study, which is maintained by the Center for Economic and Social Research (CESR) at the University of Southern California. The content of this paper is solely the responsibility of the authors and does not necessarily represent the official views of USC or UAS. This project received IRB approval from Princeton (\#0000006906) and Harvard (\#15-0673). This study can be found in the AEA RCT Registry (AEARCTR-0002404).

NBER working papers are circulated for discussion and comment purposes. They have not been peer-reviewed or been subject to the review by the NBER Board of Directors that accompanies official NBER publications.

(C) 2017 by Alexandre Mas and Amanda Pallais. All rights reserved. Short sections of text, not to exceed two paragraphs, may be quoted without explicit permission provided that full credit, including $(\odot$ notice, is given to the source. 
Labor Supply and the Value of Non-Work Time: Experimental Estimates from the Field Alexandre Mas and Amanda Pallais

NBER Working Paper No. 23906

October 2017

JEL No. C93,J22,J64

\begin{abstract}
$\underline{\text { ABSTRACT }}$
We use a field experiment to estimate the marginal value of non-work time (MVT). During a national application process for phone survey and data entry positions, we randomly offered applicants alternative wage-hour bundles. Jobseeker choices over these bundles yield estimates for the MVT as a function of hours worked. These quantities trace out a labor supply relationship. As predicted by the conventional model of the allocation of time, the substitution effect is positive. Individual labor supply is highly elastic at low hours and becomes more inelastic at higher hours. For unemployed job applicants, the opportunity cost of a full-time job due to lost leisure, household production, and other non-work activities is approximately $60 \%$ of their estimated market wage. A similar estimate is found when we reproduce elements of this experiment in a nationally-representative survey.
\end{abstract}

\author{
Alexandre Mas \\ Industrial Relations Section \\ Firestone Library \\ Princeton University \\ Princeton, NJ 08544 \\ and NBER \\ amas@princeton.edu \\ Amanda Pallais \\ Department of Economics \\ Harvard University \\ Littauer Center \\ Cambridge, MA 02138 \\ and NBER \\ apallais@fas.harvard.edu
}




\section{Introduction}

The flow value of non-work time relative to a worker's marginal product is a crucial parameter in many macroeconomic models, including search models that seek to explain wage dispersion (Hornstein, Krusell, and Violante, 2011) and the business cycle volatility of unemployment and vacancies (Shimer, 2005; Hagedorn and Manovskii, 2008). This parameter, which we denote as $z$, is typically calibrated, and for predictions of models to match the data it often requires extreme levels. For example, Hornstein, Krusell, and Violante (2011) show that $z$ has to be very low, even negative, in order for frictional wage dispersion to match observed wage dispersion. A very high value of $z$ is required to match the business cycle volatility of unemployment and vacancies in the Mortensen-Pissarides (Mortensen and Pissarides, 1994) search and matching model (Hagedorn and Manovskii, 2008). As noted by Aguiar, Hurst, and Karabarbounis (2013), understanding how individuals value marginal leisure time is necessary for computing the welfare costs of business cycles. Despite the relevance of this parameter to models of the wage structure and the business cycle, there is an active debate about its level, in large part because it is difficult to measure directly. ${ }^{1}$

We seek to fill this gap by estimating $z$ using a natural field experiment. During two national application processes, one to staff a call center and the other to fill data entry positions, we asked workers to choose between two jobs with different hours per week and randomly-assigned wages. We use observed choices to estimate the marginal value of time (MVT) at different levels of weekly work hours. These estimates trace out a labor supply relationship from which we can back out parameters that are central to numerous applications, including the value of non-work time and labor supply elasticities.

In the experiment we posted ads on a major national job board for real phone survey and data entry positions. To isolate a substitution effect and eliminate the role of commuting times the positions were described as temporary and work from home. ${ }^{2}$ Interested applicants, the majority of whom were female, were asked to choose between two positions that differed only in the number of weekly hours of work and the hourly wage. We use their choices and a simple discrete choice model to estimate the average wage workers are willing to accept to increase their working time by five hours per week. We use a similar procedure based on willingness to work overtime at varying overtime premia to estimate the wages workers are willing to accept to increase hours from 40 to 45 and from 45 to 50 hours per week. To assess generality, we weight estimates to match the characteristics of hourly workers in the Current Population Survey based

\footnotetext{
${ }^{1}$ Borgschulte and Martorell (forthcoming) estimate a variant of $z$ using reenlistment decisions of armed service personnel as a function of the unemployment rate and their sensitivity to bonus payments. Chodorow-Reich and Karabarbounis (2016) argue that cyclical variation in average hours worked and consumption results in pro-cyclical variation in $z$, but in their calibration a large range of levels of $z$ is possible.

${ }^{2}$ These characteristics accurately described the real jobs.
} 
on age, gender, race, and education. We compare our estimates with data from a survey module we designed for the nationally-representative Understanding America Study (UAS).

For unemployed job applicants, we find that below 40 work hours MVT is increasing, but gradually. At 15 hours of work, the mean MVT in our sample is $50 \%$ of the predicted market wage of jobseekers, and at 35 hours of work it is $86 \%$. Above 40 hours the MVT increases substantially. At $40-45$ hours it is $157 \%$ and at $45-50$ hours it is $163 \%$ of workers' predicted market wage. Since the collection of MVT values trace out a labor supply function, we can use the MVT estimates to compute compensated labor supply elasticities. At low hours of work labor supply is highly elastic. Below 30 hours the elasticity of hours with respect to the wage is greater than 1 . At or above 40 hours it is in the $0.4-0.6$ range.

We use the MVT estimates of unemployed applicants along with their predicted market wage to estimate the flow value of non-work time relative to their market wage, denoted by $\widetilde{z}$. For a full-time job, the estimates imply a value of non-work time relative to predicted pre-tax earnings of $\widetilde{z}=0.58$ (s.e. $=0.04$ ). We get similar estimates when we weight the sample to match the age, gender, education and race distribution of hourly workers in the United States and when we use a hypothetical choice experiment in the nationallyrepresentative Understanding America Study. Estimated $\widetilde{z}$ is moderately lower for unemployed jobseekers than for employed jobseekers but otherwise fairly stable when comparing across gender, local economic conditions, and unemployment insurance eligibility.

We then discuss how $\widetilde{z}$ (based on the market wage) and $z$ (based on marginal product) relate to one another. Diamond-Mortensen-Pissarides models imply only a small divergence between wages and marginal product, suggesting that these quantities will be close (Hall and Mueller, forthcoming). Estimates from monopsony models imply a larger divergence (Manning, 2011). In either case, the overall body of evidence suggests that $z$ is in the intermediate to higher range of values used in the search literature and in the middle of the range of Chodorow-Reich and Karabarbounis (2016)'s estimates. Because both options presented to jobseekers required them to incur any fixed cost of employment, the experiment isolates the variable component of the opportunity cost that varies with time spent working. This includes substitution away from leisure, home production and child care. ${ }^{3}$ It does not incorporate fixed costs like the cost of commuting. These fixed costs, if quantified, can be added on to our estimate. As we discuss in Section 6, commuting costs are non-negligible but small. To the extent that few of our job-seekers are receiving unemployment insurance (UI) benefits, our estimates also do not include reductions in these benefits. While based on their unemployment duration and state of residence, we estimate that almost three-quarters of unemployed applicants are potentially eligible for UI, we see little difference in the value of non-work time between these

\footnotetext{
${ }^{3}$ It does not include any fixed cost of child care.
} 
workers and applicants we classify as UI-ineligible. This may indicate, as Chodorow-Reich and Karabarbounis (2016) note that take-up is low even among eligible workers. For workers receiving benefits, the value of the reduction of UI can be quite large. For example, with a replacement rate of 0.4 a worker with UI benefits in our sample could have a value of non-work time relative to their market wage of close to unity. ${ }^{4}$

Our estimates are also useful for value of time measurement that enters into benefit-cost analyses. Value of time is often explicitly incorporated into analyses of public policies that affect work hours, such as infrastructure projects. While the market wage is a good approximation to the opportunity cost of employed workers, for the unemployed the opportunity cost of work is difficult to measure since it reflects activities that occur outside of the market, such as leisure, home production, and other non-work activities (Harberger, 1971; Bartik, 2012). This value is what we estimate.

Another noteworthy finding is that the implied labor supply function is only moderately increasing at low hours of work and becomes increasingly steeper at traditional full-time hours. The intensive margin labor supply elasticity therefore decreases with hours worked. This suggests labor supply elasticities estimated at particular hours levels may not generalize to other hours levels. Moreover, the high labor supply elasticity we estimate at low hours may rationalize the fact that there are many full-time workers in the economy and many individuals who are out of the labor force, but fewer part-time workers since there is a limited band of wages where individuals would find it optimal to work part-time.

Our study is most closely related to survey measures of the reservation wage, such as Feldstein and Poterba (1984), Holzer (1986), Krueger and Mueller (2016), and Le Barbanchon, Rathelot, and Roulet (forthcoming). ${ }^{5}$ The reservation wage is related to the flow value of non-market time, but it may differ if unemployed workers take into account the continuation value of unemployment (Mortensen, 1987) or if beliefs about attainable wages are biased (Krueger and Mueller, 2016). In addition, most reservation wage questions refer to a generic job without specifying the hours of work. Our approach allows us to measure the value of time at differing levels of hours of work. Since we find that the marginal value of non-work time is increasing in work hours, the lowest wage required for a worker to accept a 20 hour job will be lower than the lowest wage required for a worker to accept a 40 hour job. Importantly, our experimental measure is based on decisions of jobseekers in a natural environment. Our paper also adds to a small literature that uses field experiments to estimate labor supply relationships. Papers in the literature include Fehr and Goette (2007),

\footnotetext{
${ }^{4}$ However, the effective UI replacement rate of jobseekers may be lower due to cross-program effects with SNAP and Medicaid such as those found by Leung and O'Leary (2015).

${ }^{5}$ Le Barbanchon, Rathelot, and Roulet (forthcoming) analyzes reservation wages reported to the public employment service which affect workers' job search process.
} 
Goldberg (2016), and Angrist, Caldwell, and Hall (2017). We also add to a larger quasi-experimental labor supply literature in situations where hours can vary freely, including Camerer et al. (1997), Oettinger (1999), Farber (2005), Farber (2008), Ashenfelter, Doran, and Schaller (2010), Chen and Sheldon (2015), Farber (2015), Stafford (2015) and Chen et al. (2017).

The rest of the paper proceeds as follows. Section 2 lays out the experimental design, while Section 3 presents our conceptual framework and estimation strategy. Section 4 contains the main results on MVT and labor supply elasticity, while Section 5 explores heterogeneity in MVT. Finally, Section 6 concludes with a discussion of our results.

\section{Experimental Design}

The experimental design is similar to the one detailed in Mas and Pallais (forthcoming), with a number of elements that differ. Our experiment took place in 2017 during the hiring process to fill telephone interviewer and data entry positions. We posted advertisements for these real positions on a national U.S. job search platform in 80 large metro areas. The text of these ads is presented in Appendix Figure $1 .{ }^{6}$ The ads provided no information about the number of hours of work or the wage.

The ad had a link to our website where interested jobseekers could apply for a position. Once applicants followed the link, they could apply by creating an account and providing their year of birth, race/ethnicity and gender. The site prominently stated that providing race/ethnicity and gender was optional and that the questions could be skipped, though the vast majority of applicants responded. ${ }^{7}$ After registering, applicants were shown two descriptions of job positions. To eliminate the possibility of income effects, both descriptions stated explicitly that the job was temporary and was expected to last one month. In making the position temporary we also abstract from any investment rationales for taking a longer hours job in terms of learning skills that raise future earnings. ${ }^{8}$ To eliminate the role of commuting the descriptions stated that the job was work-from-home. All of these statements accurately described the real jobs. ${ }^{9}$ The two positions differed only in the number of hours of work and the hourly wage, which were randomly assigned to applicants. ${ }^{10}$ Individuals were asked to choose between a job that was $[\mathrm{X}]$ hours and a job that was $[\mathrm{X}+5]$ hours per week,

\footnotetext{
${ }^{6}$ The desired skills specified were "good communication skills", "ability to work with others", and being "used to basic computer and/or mobile applications."

${ }^{7}$ By mistake, gender and race were not asked of some applicants. Of those who were asked, $94.7 \%$ percent of applicants provided their race and $95.3 \%$ provided their gender. Overall, we have race information for $84.4 \%$ of the sample and gender information for $85.0 \%$. Results are similar if we restrict attention to the applicants for whom we collected gender or race.

${ }^{8}$ If the investment rationale is important jobseekers might be willing to accept less money for a longer hours job because they learn more valuable skills, leading to underestimates of the MVT.

${ }^{9}$ We have made 60 job offers.

${ }^{10}$ As noted in Mas and Pallais (forthcoming), we opted to show only two options to minimize cognitive load for the applicants.
} 
where $\mathrm{X}$ varied from 5 to 35 in 5 -hour increments. ${ }^{11}$ The position descriptions were as follows:

"This is a one-month work-from-home [type] position. II The position is [X] hours per week. II This position pays [Y] dollars per hour.

"This is a one-month work-from-home [type] position. II The position is [X+5] hours per week. II This position pays [Z] dollars per hour.

In this comparison [type] denotes whether the position is for phone survey or data entry work and [Y] and $[Z]$ are dollar amounts, described in detail below. All individuals were shown either two phone survey positions or two data entry positions. ${ }^{12}$

Each comparison can be summarized by the "effective" hourly wage applicant $i$ receives for working the 5 additional hours in the longer position:

$$
e_{i h}=\frac{h_{i} \times w_{i h}-\left(h_{i}-5\right) \times w_{i h-5}}{5} .
$$

where $h_{i}$ and $w_{i h}$ are the number of hours and hourly wage in the longer job, respectively and $w_{i h-5}$ is the hourly wage in the shorter job. We randomly select $e_{i h} \in\{0,4,8,12,16,18,20,24,28\}$. For the three lowest hours choices (5 vs. 10,10 vs. 15 , and 15 vs. 20 hours), we let $e_{i h}$ also take values of $\{2,6,10\}$. Piloting suggested that individuals' value of time would be lower at these hours levels and adding these lower effective wages would lead to less extrapolation.

The randomly-chosen effective wage determined the wages of the jobs. The higher hourly wage job always paid $\$ 18$. This was sometimes the shorter position and sometimes the longer position, depending on whether the effective wage was above or below $\$ 18$. The wage of the other job was adjusted so that $e_{i h}$ took the selected value. For example, for $e_{i h}=0$ in the 25 vs. 30 hour comparison, the 25 and 30 hour jobs pay the same weekly amount. Thus, the 25 hour job must pay $\$ 18$ per hour and the 30 hour job must pay $\$ 15$ per hour. ${ }^{13}$ Without income effects, willingness to accept the higher hour position will depend on the effective wage $e_{i h}$, but not on the wage levels presented, $w_{i h}$ and $w_{i h-5} .{ }^{14}$ Appendix Table 1 shows the wages for each

\footnotetext{
${ }^{11}$ That is, the choices were 5 vs. 10,10 vs. 15,15 vs. 20,20 vs. 25,25 vs. 30,30 vs. 35 , and 35 vs. 40 hours per week.

${ }^{12}$ The $9 /$ indicates a line break.

${ }^{13}$ We do not include a $\$ 28$ effective wage for the 5 vs. 10 hour comparison as this would require the 5 hour job to pay $\$ 8$, below the minimum wage in many of the cities in our experiment.

${ }^{14}$ If there are income effects, higher values of $w_{i h}$ and $w_{i h-5}$ will result in a higher break-even effective wage for working five more hours.
} 
effective wage/hours combination. We rounded all wages to the nearest $\$ 0.10$, so the actual effective wage shown is not always a perfectly round dollar amount. In our estimation, we use the actual (non-rounded) effective wage.

Appendix Figure 2 provides an example of the page with the job descriptions. This page was designed to ensure that only the hour and wage information would affect workers' choices. To this end we referred to jobs only by number to minimize the extent to which job titles would affect workers' choices. ${ }^{15}$ To maximize the fraction of applicants who read both job applications carefully, we forced applicants to physically click on each position to see the job descriptions. We also required applicants to manually type the number of the job they preferred to lessen the tendency to simply click through to the next page. We randomized which job was presented first.

We told applicants that the type of work in both jobs was the same and asked them which job they would choose if both were available. We told applicants that if they were hired they would be offered the position they chose, thereby making this a real decision. However, we also told applicants that they would be considered for all open positions. This was done to give us flexibility to also offer them more generous alternatives. We emphasized that their decision would not affect whether they were hired. All of these statements were truthful. Most workers (73\%) who made a job choice completed the application. Our main analysis uses all choices made, but we show in an appendix table that the results are similar if we restrict attention to workers who ultimately applied for the jobs.

We are also interested in how workers value their time above 40 hours per week. The difficulty is that by the Fair Labor Standards Act (FLSA) hourly workers have to get an overtime premium of at least 1.5 times their hourly pay for hours above 40. If we were to present the choice of 40 versus 45 hours or 45 versus 50 hours without mentioning overtime, it would be unclear how to interpret the choices since some applicants might assume there was overtime pay while others would not. Therefore, for randomly-selected applicants we implemented a second set of treatments where we offered the choice of either (1) a 40 versus 45 hour position or (2) a 45 or 50 hour position. Here, we randomly varied the overtime premium for hours over 40. The 40 hour choice read:

"This is a one-month work-from-home [type] position. II The position is 40 hours per week. II This position pays 18.00 dollars per hour.

\footnotetext{
${ }^{15}$ These numbers were randomly assigned to jobs. The numbers were also balanced within comparisons, so if some individuals were given a choice between Position \#78 which was 30 hours per week and Position \#81 which was 35 hours, other participants would be faced with a choice between Position \#81 which was 30 hours and Position \#78 which was 35 hours.
} 
The 45 and 50 hour position descriptions read:

"This is a one-month work-from-home [type] position. II The position is [45/50] hours per week. II This position pays 18.00 dollars per hour for the first 40 hours and [EW] dollars per hour for the remaining [5/10] hours.

Here, $E W$ is the effective wage since both jobs pay the same hourly wage until the final five hours. In the 45 versus 50 hour choice, the same overtime wage is utilized in both positions. We randomly select $E W \in\{27,29,31,33,35\}$. Due to the FLSA, \$27 was the lowest overtime wage we could offer. A concern for comparing MVT estimates above and below 40 hours is that perhaps applicant responses differ depending on whether they are comparing average wages (below 40 hours) or marginal wages (above 40 hours). To assess this possibility we ran a separate validation study where we offered a 35 versus 40 hour choice with the same effective wages to different applicants, randomly phrasing the comparison as either (1) two differing wage rates or (2) the same wage rate up to 35 hours and a separate marginal rate for hours between 35 and 40 . As we will show, both methodologies give similar results. ${ }^{16}$

Another issue is that for the 40 vs. 45 hour comparison there is significant extrapolation in calculating the MVT since mean MVT is below \$27 and at an effective wage of \$27 about three quarters of applicants choose the 45 hour job. Below we describe our approach to dealing with this extrapolation. Our estimates of the flow value of non-work time will not utilize MVT estimates above 40, so these issues are only relevant for evaluating the shape of the labor supply curve.

As found in Mas and Pallais (forthcoming), despite the fact that we forced applicants to physically click on the job descriptions and type the number of their preferred job, some applicants were inattentive. On the page after individuals made their choice, we asked them to report the number of hours they chose. They were presented with 11 choices (5 through 50 hours in 5 hour increments and "I don't remember"). Overall, 0.6\% of people said they didn't remember and $9.0 \%$ chose incorrectly, indicating an $10.6 \%$ inattention rate. ${ }^{17} \mathrm{We}$ account for inattention in our estimation as described in Section 3. In practice, this inattention matters little when estimating the average value of time, but affects estimated dispersion.

\footnotetext{
${ }^{16}$ An alternative to our approach would be to vary the marginal wage (as in the overtime comparisons) at all hours levels. We chose not to do this because of the minimum wage constraint. Varying the marginal wage only would not allows us to detect MVT values below the minimum wage which, depending on the state, are substantially higher than median MVT we estimate at low hours.

${ }^{17}$ To determine the inattention rate, we add the number of people reporting they did not remember and the fraction choosing incorrectly multiplied by $10 / 9$. The $10 / 9$ factor is to correct for the fact that $1 / 10$ of the people who were inattentive but didn't report not remembering chose correctly by chance.
} 
Our focus in the paper will be on unemployed jobseekers because for this group there is a natural interpretation of MVT as the value of non-work time. For employed jobseekers, MVT likely includes not just leisure and household production but also possibly the wage in other jobs if they have to substitute hours between jobs. For completeness, we show estimates for the full sample as well.

\section{Conceptual and Econometric Framework}

Applicants are shown a shorter and a longer job, whose hours and wages are given by $\left\{h_{i}-5, w_{i h-5}\right\}$ and $\left\{h_{i}, w_{i h}\right\}$, respectively. We use applicants' choices over a range of effective wages to determine the average mean value of time between $h-5$ and $h$ weekly hours of work $\left(\overline{M V T_{h}}\right)$. We estimate $z$ by combining $\overline{M V T_{h}}$ estimates over different values of $h$ up to 40 hours per week.

Applicant $i$ chooses the higher hour package if $U\left(h_{i} w_{i h}, h_{i}\right)>U\left(\left(h_{i}-5\right) w_{i h-5}, h_{i}-5\right)$. If the individual is fully attentive, she chooses the longer job if the effective wage $\left(e_{i h}\right.$, defined in Equation 1) exceeds her average hourly opportunity cost of working 5 additional hours $\left(M V T_{i h}\right)$, that is, if $M V T_{i h}<e_{i h}$. Assuming a logistic distribution for $M V T_{i h}$ (an assumption that we can assess visually), we can estimate a logit with an indicator for choosing the longer position as the dependent variable and the effective wage $e_{i h}$ as the explanatory variable. In this setup, our estimate of $\overline{M V T_{h}}$ is the estimated intercept divided by the slope coefficient.

To account for the fact applicants are inattentive, we estimate a mixture model of the form $\operatorname{Pr}\left(h_{i}=\right.$ $\left.1 \mid e_{i h}\right)=P_{e}(1-\alpha)+\left(1-P_{e}\right) \alpha=F(b e+c ; \mu, \sigma)(1-2 \alpha)+\alpha$ using maximum likelihood (ML), where $\operatorname{Pr}\left(h_{i}=1 \mid e_{i h}\right)$ is the probability of choosing the longer-hour job and $P_{e}$ is the probability that an attentive individual truly prefers the longer-hour job. Here, $2 \alpha$ is the fraction of individuals who are inattentive ( $10.6 \%$ on average), calculated from whether individuals correctly recalled the number of hours they chose. Under the assumption that inattentive individuals make their choice at random, $\alpha$ will choose the longer job and $\alpha$ will choose the shorter job, regardless of the wages presented. (This inattention correction largely only affects estimated dispersion.) We assume a logistic cdf, though other cdfs provide similar estimates. In this model, our estimate of $\overline{M V T_{h}}$ is the intercept divided by the coefficient on the effective wage term.

We modify this procedure to estimate MVT for the overtime treatments. The FLSA necessitates we offer high effective wages in these treatments, so estimating the average MVT requires extrapolation. Estimating the above model, we constrain the intercept, $\operatorname{Pr}\left(h_{i}=1 \mid e_{i h}=0\right)$, based on the intercept in the non-overtime treatments, which allows the non-overtime treatments to inform the extrapolation, dramatically increasing precision in the 40 vs. 45 hour choice. Our preferred specification uses the estimated intercepts at lower hour 
treatments to predict the intercept as a function of $h$. We then constrain the intercepts in the two overtime treatments as the predicted intercepts at $h=45$ and $h=50$. We show estimates under different methods of picking the intercept constraint (e.g., using the average intercept or the estimated intercept in the 35 vs. 40 hour comparison) and results are very similar. Adding this constraint has very little effect on estimates of mean MVT for the 45 vs. 50 hour treatment, where there was less extrapolation and imprecision without it.

$M V T_{i h}$ is the wage that makes individual $i$ indifferent between working $h_{i}-5$ and $h_{i}$ hours per week. Because theoretically work hours are set to equate the wage with the shadow value of time (Becker, 1965; Gronau, 1977; Heckman, 1974), $M V T_{i h}$ is an approximation to $i^{\prime} s$ inverse labor supply function between $h_{i}-5$ and $h_{i}$ hours. Note that applicants cannot choose their exact desired number of hours; they can only choose $h_{i}-5$ or $h_{i}$ hours. If their labor supply function is strictly increasing, at $M V T_{i h}$ dollars per hour, their inverse labor supply function $w_{i}($.$) has w_{i}\left(h_{i}-5\right)<M V T_{i h}<w_{i}\left(h_{i}\right)$. That is, their value of time at $h_{i}$ hours exceeds their average value of time between $h_{i}-5$ and $h_{i}$ hours $\left(M V T_{i h}\right)$ which exceeds their value of time at $h_{i}-5$ hours. At a wage of $M V T_{i h}$, they would choose to work strictly between $h_{i}-5$ and $h_{i}$ hours per week. Because all jobs were explicitly temporary (1 month long), we assume there are no income effects. Without income effects, the marginal rate of substitution between consumption and leisure at a given number of hours does not depend on the consumption level; in this case, $M V T_{i h}$ does not depend on the wage paid up to $h_{i}-5$ hours.

Note that $\overline{M V T_{h}}$ is an approximation to the average individual inverse labor supply curve. It gives the wage the average individual needs to work $h$ (as opposed to $h-5$ ) hours. It is not an approximation to an aggregate labor supply curve. That is, it is not the wage at which, across the population, hours of work average $h .^{18}$

To form our estimate of the average $z$, the flow value of non-work time for a full-time 40 hour job, we utilize the fact that $\overline{M V T_{h}}$ provides the average value of time between $h-5$ and $h$ hours. Our experiment does not provide the average value of time between 0 and 5 hours since no applicants were given that choice. We estimate $\overline{M V T_{5}}$ using a linear prediction determined by $\overline{M V T_{10}}$ and $\overline{M V T_{15}}$. Other estimation methods give similar results. Then our estimate of the average $\widetilde{z}$ is simply

$$
\widetilde{z}=\frac{1}{\hat{w}}\left[\frac{5\left(\overline{M V T_{5}}+\overline{M V T_{10}}+\ldots+\overline{M V T_{40}}\right)}{40}\right] .
$$

Here, $\hat{w}$ is average predicted pre-tax hourly market wage. This term is calculated using applicant gender, race, education, and age and data from the 2016 Current Population Survey Merged Outgoing Rotation

\footnotetext{
${ }^{18}$ To see this, imagine that at a wage of $\overline{M V T_{h}}$, individuals with $M V T_{i h}>\overline{M V T_{h}}$ may choose to work only a few hours less than $h$, whereas individuals with $M V T_{i h}<\overline{M V T_{h}}$, may choose to work many more hours. In this case, average hours would exceed $h$.
} 
Groups (CPS MORGs). Specifically, we predict an applicant's wages as the average wage of hourly workers in the CPS living in cities with his or her gender, race, and education, and in his or her 5-year age bin. ${ }^{19}$ For unemployed applicants we discount the resulting wage by $6 \%$, which is the estimated wage penalty for employed hourly workers who left or lost their jobs in the last three years in the 2016 CPS Displaced Worker Supplement. ${ }^{20}$ Then, $\hat{w}$ is applicants' average predicted wage.

After estimating the model on each treatment sample individually, we combine the parameter estimates and covariance matrices from all treatments (including overtime treatments) and calculate robust standard errors on MVT and $\widetilde{z}$ estimates using the delta method.

\section{Results}

\subsection{Descriptive Statistics and Randomization Assessment}

The first column of Table 1 provides descriptive statistics for our sample. The majority (83\%) of our sample is female. This is in large part because phone survey and data entry workers are primarily women. Applicants average 34 years old. The plurality of our sample has some college but no degree, while the rest of the sample is split between those with high school and college degrees. Our sample is also relatively racially diverse. Most of our sample (59\%) is currently unemployed, the majority (64\% of those) for under three months. Based on the length of their unemployment spell and their state of residence, we estimate that $72 \%$ of these individuals are potentially eligible for UI. ${ }^{21}$

Table 2 assesses the randomization. For each of the nine different hours choices, we regress six applicant characteristics on indicators for each effective wage the applicant was randomly assigned. We limit the sample to applicants who made a job choice. If the randomization was implemented correctly, the effective wage indicators should not be jointly significant. We consider only the variables that were collected before

\footnotetext{
${ }^{19}$ When applicants didn't report one or more of the characteristics used to assign wages, we assigned them the average wage of CPS respondents with the characteristics they did report, weighted by the distribution of the missing characteristic(s) in the experiment data. For example, consider a 27 year-old white woman who didn't report her education. From the overall distribution of education levels in the data, her predicted wage is (0.02)*(average CPS wage of 25-30 y/o white women with less than HS) + $(0.27) *$ (average CPS wage of 25-30 y/o white women with a high school degree) $+(0.44) *($ average CPS wage of $25-30$ y/o white women with some college $)+(0.24) *($ average CPS wage of $25-30$ y/o white women with a college degree $)+(0.04) *($ average CPS wage of 25-30 y/o white women with an advanced degree).

${ }^{20}$ Specifically, the sample is all employed hourly workers in the 2016 Displaced Worker Supplement. We regress log wages on a quadratic in age, education dummies, race/ethnicity dummies, gender dummies, and an indicator for whether the respondent left or lost his or her job in the previous three years.

${ }^{21}$ We consider individuals as potentially eligible for UI if they have been unemployed for less than their state's maximum duration of UI benefits. We know only whether individuals have been unemployed for less than 3 months, 3 to 6 months, or more than 6 months. We consider individuals unemployed 3 to 6 months as ineligible if the maximum benefit duration in their state is less than 4.5 months. Otherwise they are considered UI eligible. UI eligibility is still an approximation since people categorized as eligible may be ineligible for other reasons, like quitting their previous job or not having a sufficiently long employment history. Of course, UI-eligible workers may also not take up benefits.
} 
the jobs were presented: gender, race, and age. The table reports the p-value for each of the 54 regressions. The effective wage indicators are jointly significant for predicting the demographic characteristic in four regressions, a number we may reasonably expect to see by chance. Appendix Table 2 replicates this table, limiting the sample to workers who are unemployed. Observable characteristics look fairly balanced along this dimension as well, though with one additional demographic characteristic that is jointly significant. Appendix Table 3 shows that, consistent with random assignment, unemployed workers in each hours choice have similar demographic characteristics. Appendix Figures 3 and 4 show that neither the probability of making a choice nor the probability of continuing the application after the choice and entering the remaining demographic information is related to effective wages.

\subsection{Main Treatments}

We begin with visual nonparametric and parametric summaries of the data. We construct binned scatterplots of the inattention-corrected fraction of unemployed applicants who chose longer hours against the effective wage $\left(e_{i h}\right)$ for each hours choice. ${ }^{22}$ We overlay the scatterplot with the ML fit, which can be interpreted as a cdf of the MVT distribution since it is monotonic and bounded between 0 and 1. These scatterplots are shown in Figure 1. Consistent with economic principles, there is a positive relationship between choosing the higher hours option and the effective wage in all cases. In all cases the logit assumption appears reasonable. Inattention-uncorrected figures (presented in Appendix Figure 5) look similar. Appendix Figure 6 presents data from the overtime validation study where we compare choices between 35 and 40 hour jobs when we show (1) separate hourly wages and (2) the same wage up to 35 hours per week and a higher marginal wage after 35 hours. As discussed earlier, we do this to check whether the different wage framing in the overtime study influences the responses. The estimates are quite close and we conclude that responses do not appear sensitive to framing.

Table 3 presents estimates of the mean and quantiles of MVT by hour of work for unemployed jobseekers. ${ }^{23}$ For reference, using the 2016 CPS we predict that the market wage for the average unemployed job seeker in our sample is $\$ 13.93$ pre-tax. (The predicted wages for different subgroups are in Appendix Table 7.) At this wage, on a pre-tax basis there is a large amount of worker surplus for the first few hours someone works. The estimated mean MVT is $\$ 4.63$ between 5 and 10 hours of work and increases to $\$ 8.84$ per hour between 20 and 25 hours of work. MVT increases relatively linearly through the first 40 hours, reaching

\footnotetext{
${ }^{22}$ At a given hours level $h$, the inattention-corrected fraction is $\left(Y_{h}-\hat{\alpha}\right) /(1-2 \hat{\alpha})$, where $Y_{h}$ is the fraction of applicants who chose longer hours when given the choice of $h$ or $h-5$ hours. The presented fits are estimated off of the individual-level data, not these points.

${ }^{23}$ Inattention-uncorrected estimates are in Appendix Table 4, while estimates for the full sample (not limited to unemployed applicants) are in Appendix Table 5 and estimates limited to unemployed workers who applied for the job are in Appendix Table 6.
} 
about $\$ 15$ between 30 and 40 hours of work. After 40 hours the slope MVT increases at a higher rate, reaching almost $\$ 22$ between 40 and 45 hours of work. ${ }^{24}$ Thus, on average, workers' MVT equals their average predicted market wage in the 30 to 40 hours of work per week range. This implies that the average job applicant in our sample would work full-time at their expected market wage. Overall, we calculate $\widetilde{z}=0.58$. Estimates that are weighted to match the age, gender, race, and education of hourly workers in the CPS are shown in Table 4, again for the unemployed sample. ${ }^{25}$ Weighting results in very similar values of non-work time. ${ }^{26}$

In the standard formulation of the static labor supply model, hours are set to equate wages with the MVT. The collection of MVT values as a function of hours therefore traces out a labor supply relationship. The labor supply function is plotted in Figure 2. The figure shows the estimated values connected by linear segments. We show the median as well as the 25 th and 75 th percentiles of the function. ${ }^{27}$ The labor supply function is moderately upward sloping and becomes steeper around 40 hours of work.

Figure 3 plots the implied labor supply elasticity by hours worked. To compute the elasticity we first estimate a smoothed labor supply relationship by fitting a quartic polynomial to the MVT points shown in Figure 2. Elasticities are then read off of the smoothed relationship. Labor supply is highly elastic at low hours levels, exceeding 1 until 25 to 30 hours of work. At that point they drop, reaching 0.5 to 0.6 after 40 hours per week. Table 5 shows the elasticities implied by the quartic model and several other smoothing models, while Figure 4 shows the individual MVT points with the quartic fit. Depending on the model, elasticities after 40 hours are in the 0.4 to 0.6 range. Appendix Figure 7 shows that the labor supply function looks similar when not limited to unemployed applicants, while Appendix Table 10 shows that elasticities look similar as well.

\section{Heterogeneity in Valuations}

Figure 1 and Table 3 show that there is substantial heterogeneity in MVT. The 25th percentile of MVT is below $\$ 2$ per hour until about 30 hours per week. On the other hand, at the lowest hours choices the 75th percentile MVT is close to double the median, and it increases to $\$ 33$ per hour by 40 to 45 hours per week.

\footnotetext{
${ }^{24}$ Appendix Table 8 shows the overtime estimates are robust to different intercept constraints.

${ }^{25}$ Specifically, we weight the full sample to match the observable characteristics of hourly workers in the CPS and then limit the sample to unemployed workers.

${ }^{26}$ Appendix Table 9 shows descriptive statistics for the weighted samples, compared to the unweighted experiment and CPS samples.

${ }^{27}$ Note that to interpret these as labor supply functions for a given individual, we need to make the assumption that individuals have non-crossing inverse labor supply functions. That is for all individuals $i, j$ and hours levels $h$, and $h^{\prime}$ if $M V T_{i h}>M V T_{j h}$, then $M V T_{i h^{\prime}}>M V T_{j h^{\prime}}$.
} 
We have explored whether any of this heterogeneity is explained by individual characteristics. Table 6 shows estimates of $\widetilde{z}$ by gender, employment status, and potential UI eligibility. For each subgroup, we estimate the MVT separately. To estimate $\widetilde{z}$, we also calculate separate predicted wages by subgroup, estimating each individual's predicted wage as described above and averaging them within the subgroup.

Our estimate of $\widetilde{z}$ is slightly, but insignificantly larger for women $(\widetilde{z}=0.64)$ than for men $(\widetilde{z}=0.59){ }^{28}$ Estimated $\widetilde{z}$ is somewhat larger for employed $(\widetilde{z}=0.66)$ than unemployed $(\widetilde{z}=0.58)$ jobseekers, though this difference is not statistically significant at conventional levels $(p=0.14)$. It is unsurprising that employed jobseekers have a higher estimated value of time, since their alternative to working in the job we advertise is possibly more hours in another job. As we have discussed, a cleaner estimate of the flow value of non-work time is from the unemployed sample since for this group the alternative is truly not working. Among the unemployed, estimated $\widetilde{z}$ is similar among those who are potentially eligible for UI benefits and those who are not. This may indicate low take-up of UI among those we classify as UI-eligible.

In Table 7 we examine how MVT varies with the predicted market wage of jobseekers, and how $\widetilde{z}$ varies with labor market conditions. Here, again we limit the sample to unemployed applicants. To gain power, we stack the data for all the (non-overtime) hours choices and estimate a model where the dependent variable is choosing the longer hours job. The independent variables are an indicator for every hours choice and the interaction of the effective wage with each hours choice dummy. We also include terms for the individual's predicted wage and the interaction of predicted wage and effective wage. This allows an individual's predicted wage to affect both the intercept and the slope of the ML fit, but to affect the different hours choices in the same way.

In the first panel of Table 7 we report the MVT for a jobseeker with a mean predicted market wage among unemployed applicants ( $\$ 13.93$ per hour) and the MVT for a predicted wage that is one standard deviation (\$3.82) higher than the mean, and one standard deviation lower. MVT significantly increases with the predicted wage, but not one-for-one. A two standard deviation increase in predicted wage (\$7.64) increases the average MVT by $\$ 2.10$ per hour $(p=0.06)$.

The second two panels show how $\widetilde{z}$ varies with the MSA unemployment rate and the deviation of this rate from its historical mean. We use data from the BLS's Local Area Unemployment Statistics program to calculate the unemployment rate of the MSA in the month of the job posting (April, May, or June 2017) and the difference between this rate and its 10-year average. Then, separately, we estimate how MVT varies

\footnotetext{
${ }^{28}$ This comparison only includes men and women applying for phone survey and data entry jobs (primarily female positions) and thus may not be representative of men's $\widetilde{z}$ more generally. Nevertheless, in the nationally-representative UAS, we also estimate slightly, but insignificantly larger $\widetilde{z}$ 's for women $(\widetilde{z}=0.62)$ than men $(\widetilde{z}=0.60)$. For comparisons by gender we combine employed and unemployed jobseekers to maximize statistical power. Separate estimates by gender of the mean and quantiles of MVT for each hours choice are in Appendix Table 11.
} 
with these two variables as we did for predicted wages. In presenting $\widetilde{z}$ 's for areas with higher and lower unemployment rates, we allow predicted wages to vary with the unemployment rate, though in practice, this does not matter much. ${ }^{29}$ We do not find that $\widetilde{z}$ varies significantly with either measure of local economic conditions, though we do not have power to rule out reasonable variation with economic conditions.

We can use variation in MVT to assess the likely variation in $\widetilde{z}$ under the assumption that individual labor supply curves do not cross: that is, if $M V T_{i h}>M V T_{j h}$ then $M V T_{i h^{\prime}}>M V T_{j h^{\prime}}$ for all individuals $i$ and $j$ and hours levels $h$ and $h^{\prime}$. Estimating the quantiles of $z$ presents challenges because we don't have external information on the market wage of jobseekers by MVT quantile. If we also assume the market wage for the quantiles is the same as the mean, the 25 th and 75 th percentiles of $z$ are 0.16 and 0.99 , respectively. However, given the finding that MVT is increasing in the market wage, the spread of the $\widetilde{z}$-quantiles is likely exaggerated. Since low MVT people have a lower market wage, their value of $\widetilde{z}$ is going to be higher than when using the mean wage.

We utilize the Understanding America Survey (UAS) to explore the external validity of our results. The UAS is a nationally-representative survey in which a panel of randomly-selected individuals responds to web-based surveys. ${ }^{30}$ We asked hourly workers:

Imagine that you are applying for a new job in the same line of work as your [main, last] job and you have been offered two positions. Both positions are the same as your [main, last] job and to each other in all ways including benefits, other than the work schedule and how much they pay. Assume you can take no other jobs. II Please read the descriptions of the positions below. II Position 1) This position is X+10 hours per week and has a fixed Monday-Friday daytime schedule. The position pays \$Y per hour. II Position 2) This position is $X$ hours per week and has a fixed Monday-Friday daytime schedule. The position pays $\$ Z$ per hour. II Which position would you choose?

Here, "X" is 10,20 , or 30 hours per week and "Y" - the hourly wage in the longer job - is a worker's current hourly wage. The hourly wage in the shorter job, "Z", is a random multiple of the worker's current hourly wage: $[65 \%, 80 \%, 90 \%, 95 \%, 98 \%, 100 \%, 102 \%, 105 \%, 110 \%, 120 \%, 135 \%]$. We use these wages to calculate effective wages using Equation (1). [Main, last] is "main" for employed workers and "last" for unemployed workers. ${ }^{31}$ Each employed or unemployed participant answered all four hypotheticals. The

\footnotetext{
${ }^{29}$ We regress predicted wages on the local unemployment rate (or the unemployment rate relative to trend) and predict wages for areas with rates one standard deviation above and below the mean.

${ }^{30}$ The UAS is run out of the University of Southern California and established and directed by Arie Kapteyn. It is closely related in design to the Rand American Life Panel. As is the case for most surveys, because of non-response the UAS is not technically representative, rather it is weighted to be representative. Importantly though, it covers all occupations rather than just the two we use for our field study. Appendix A contains additional details on the sample selection for the UAS analysis.

${ }^{31}$ To measure inattention, we gave individuals a choice between two 40 hour-per-week jobs, one of which paid more than the other. Our inattention rate is double the fraction of people who chose the lower-paying job. Half of inattentive individuals who choose at random will choose the lower-paying job by chance.
} 
order of the questions was randomized as was which job was Position 1.

Table 6 shows that the UAS estimate is $\widetilde{z}=0.61$ (s.e. $=0.03$ ). This value is very similar to the full sample $\widetilde{z}$ that combines employed and unemployed applicants $(\widetilde{z}=0.63) .{ }^{32}$

\section{Discussion and Conclusion}

It is known that a significant component of time in unemployment is spent on leisure and home production (Aguiar, Hurst, and Karabarbounis, 2013). Our estimates suggest that, clearly, this use of time is valued. To compare our estimates to assumed or calibrated quantities for the value of non-work time used in the search literature, we need to account for possible wedges between wage and marginal product, taxes, and fixed costs of employment. We discuss these issues below.

\section{Wages versus Marginal Product}

Since marginal product likely exceeds or equals the wage, estimates of $z$ based on marginal product will likely be weakly smaller than those based on the wage. Estimates of the elasticity of labor supply to the firm provide guidance on the degree of this divergence. In the dynamic monopsony framework the percent difference between marginal product and the wage ("the rate of exploitation") equals the inverse of the elasticity of labor supply to the firm (Robinson, 1969). Assuming an elasticity of around 4, which is in the range of estimates reported in Manning (2011) and implies that employers have significant market power, the marginal product will be $25 \%$ higher than the wage. Therefore $z$ will be $\left(1-\frac{1}{1.25}\right)=20 \%$ lower than $\widetilde{z}$. Calibrations of Diamond-Mortensen-Pissarides models yield a substantially smaller divergence between wages and marginal product. Hall and Milgrom (2008) calculate a ratio of the wage to marginal product of 0.985 (see also Hall and Mueller, forthcoming), implying a value of $z$ based on marginal product that is very close to the one we estimate.

\section{Taxes}

Estimates of $z$ are often based on the after-tax marginal product (Chodorow-Reich and Karabarbounis, 2016) whereas the estimate of $\widetilde{z}$ we have reported is not. Applying an effective tax rate of 0.2 increases $z$ by $\left(\frac{1}{0.8}-1\right)=25 \%$.

\section{Fixed Costs of Employment}

Estimates of the opportunity cost of work will be higher if one were to add in fixed costs such as the cost of commuting. Estimates of the valuation of travel time are reviewed in Small (2012). A reasonable approximation is that commute time is valued at half the gross wage. The average worker spends approxi-

\footnotetext{
${ }^{32}$ UAS estimates are virtually unchanged if we weight the UAS sample to match the observable characteristics of the applicants in the experiment.
} 
mately one hour a day commuting. With these estimates we would add 0.06 to the estimated value of $z$. To the extent that individuals in our sample are not collecting UI benefits, our estimates also do not fully capture the reduction in UI benefits that accompanies working. A conservative estimate of the UI replacement rate is 0.3 , though only a small fraction of jobseekers are on UI at any point in time. A fixed cost that is more difficult to quantify is any fixed component to child care, such as time spent searching for child care providers.

Taking into account the above differences, $z$ based on after-tax marginal product will be quite close to our estimate $\widetilde{z}=0.58$ since the conversion from wage to marginal product assuming the monopsony case is effectively canceled out by making the denominator an after-tax quantity. Accounting for commuting times, $z$ will be only moderately higher. It will be substantially higher for UI recipients or if we assume a smaller wedge between the wage and marginal product. Therefore, our estimate is in the intermediate to upper end of the literature which, as discussed, largely comes from calibrations. Chodorow-Reich and Karabarbounis (2016) report a range of assumed estimates of 0.45-0.5 prior to the Hagedorn and Manovskii (2008) study and 0.73-0.92 after. ${ }^{33}$ In their calibration, they report $z$ in the range of 0.47-0.75 based on post-tax marginal product. Our estimate of the value of non-work time relative to after-tax marginal product of $z=0.60$ falls in the middle of this range and provides support for their utility function calibration approach that is the basis for estimating the cyclicality of the value of time.

The fact that labor supply is highly elastic at low hours of work is not incompatible with the labor literature that estimates relatively inelastic labor supply at the intensive margin. Our sample is comprised primarily of women, who tend to have higher labor supply elasticities. Additionally, the less elastic part of the labor supply relationship corresponds to the range of hours where most people work. Since most workers are working close to full-time, any local variation in the wage will show only moderate variation in hours since workers tend to be located in the more inelastic region of the labor supply function.

The shape of the labor supply function we estimate can potentially rationalize the distribution of hours in the economy. In the U.S. labor market there are many full-time workers, many individuals who are out of the labor force entirely, and fewer who choose part-time work. This distribution can be explained by the labor supply relationship we estimate, the key feature being that it goes from more elastic to more inelastic. There are relatively few part-time workers because part-time work lies on the elastic part of the labor supply curve, implying a limited wage range where a worker would find it optimal to work intermediate hours. Small positive deviations in the wage push workers to full-time work, and small negative deviations push

\footnotetext{
${ }^{33}$ Among the papers that calibrate or assume $z$ values are Mortensen and Nagypal (2007), Costain and Reiter (2008), Bils, Chang, and Kim (2012), Hagedorn and Manovskii (2008), Hall and Mueller (forthcoming), Hall and Milgrom (2008), Hornstein, Krusell, and Violante (2011), and Shimer (2005).
} 
them out of the labor force.

The estimated value of $z$ can also be applied to benefit-cost analyses that involve valuation of time for unemployed workers. To do this, an analyst could compute the predicted market wage of individuals in the study, given their characteristics, and the relevant opportunity cost of a full-time job would be $60 \%$ of that value. 


\section{References}

Aguiar, Mark, Erik Hurst, and Loukas Karabarbounis, "Time Use During the Great Recession," American Economic Review, 2013, 103 (5), 1664-1696.

Angrist, Joshua D., Sydnee Caldwell, and Jonathan V. Hall, “Uber vs. Taxi: A Driver's Eye View,” July 2017. Working Paper.

Ashenfelter, Orley, Kirk Doran, and Bruce Schaller, "A Shred of Credible Evidence on the Long-run Elasticity of Labour Supply,” Economica, 2010, 77 (308), 637-650.

Bartik, Timothy J., "Including Jobs in Benefit-Cost Analysis," Annual Review of Resource Economics, 2012, 4 (1), 55-73.

Becker, Gary S., “A Theory of the Allocation of Time,” Economic Journal, 1965, pp. 493-517.

Bils, Mark, Yongsung Chang, and Sun-Bin Kim, “Comparative Advantage and Unemployment," Journal of Monetary Economics, 2012, 59 (2), 150-165.

Borgschulte, Mark and Paco Martorell, "Paying to Avoid Recession: Using Reenlistment to Estimate the Cost of Unemployment," American Economic Journal: Applied Economics, forthcoming.

Camerer, Colin, Linda Babcock, George Loewenstein, and Richard Thaler, "Labor Supply of New York City Cab Drivers: One Day at a Time," Quarterly Journal of Economics, 1997, 112 (2), 407-441.

Chen, M. Keith and Michael Sheldon, "Dynamic Pricing in a Labor Market: Surge Pricing and Flexible Work on the Uber Platform,” 2015. Working Paper.

_ , Judith A. Chevalier, Peter E. Rossi, and Emily Oehlsen, "The Value of Flexible Work: Evidence from Uber Drivers," March 2017. National Bureau of Economic Research Working Paper No. 23296.

Chodorow-Reich, Gabriel and Loukas Karabarbounis, "The Cyclicality of the Opportunity Cost of Employment," Journal of Political Economy, December 2016, 124 (6), 1563-1618.

Costain, James S. and Michael Reiter, "Business Cycles, Unemployment Insurance, and the Calibration of Matching Models," Journal of Economic Dynamics and Control, 2008, 32 (4), 1120-1155.

DiNardo, John, Nicole M. Fortin, and Thomas Lemieux, "Labor Market Institutions and the Distribution of Wages, 1973-1992: A Semiparametric Approach,” Econometrica, 1996, 64 (5), 1001-1044.

Farber, Henry, "Is Tomorrow Another Day? The Labor Supply of New York City Cab Drivers," Journal of Political Economy, 2005, 113 (1), 46-82.

_ , "Reference Dependent Preferences and Labor Supply: The Case of New York City Taxi Drivers," American Economic Review, June 2008, 98 (3), 1069-1082.

_ , "Why you Can't Find a Taxi in the Rain and Other Labor Supply Lessons from Cab Drivers," Quarterly Journal of Economics, July 2015, 130 (4), 1975-2026.

Fehr, Ernst and Lorenz Goette, "Do Workers Work More if Wages are High? Evidence from a Randomized Field Experiment,” American Economic Review, March 2007, 97 (1), 298-317.

Feldstein, Martin and James Poterba, "Unemployment Insurance and Reservation Wages," Journal of Public Economics, 1984, 23 (1-2), 141-167. 
Goldberg, Jessica, "Kwacha Gonna Do? Experimental Evidence about Labor Supply in Rural Malawi," American Economic Journal: Applied Economics, January 2016, 8 (1), 129-149.

Gronau, Reuben, "Leisure, Home Production, and Work-the Theory of the Allocation of Time Revisited," Journal of Political Economy, 1977, 85 (6), 1099-1123.

Hagedorn, Marcus and Iourii Manovskii, "The Cyclical Behavior of Equilibrium Unemployment and Vacancies Revisited," American Economic Review, September 2008, 98 (4), 1692-1706.

Hall, Robert E. and Andreas I. Mueller, "Wage Dispersion and Search Behavior: the Importance of Non-Wage Job Values," Journal of Political Economy, forthcoming.

- and Paul R. Milgrom, "The Limited Influence of Unemployment on the Wage Bargain," American Economic Review, September 2008, 98 (4), 1653-74.

Harberger, Arnold C., "On Measuring the Social Opportunity Cost of Labour," International Labour Review, 1971, 103 (6), 559-579.

Heckman, James, "Shadow Prices, Market Wages, and Labor Supply," Econometrica, 1974, 42 (2), 679694.

Holzer, Harry J., "Reservation Wages and their Labor Market Effects for Black and White Male Youth," Journal of Human Resources, 1986, pp. 157-177.

Hornstein, Andreas, Per Krusell, and Giovanni L. Violante, "Frictional Wage Dispersion in Search Models: A Quantitative Assessment," American Economic Review, December 2011, 101 (7), 2873-2898.

Krueger, Alan B. and Andreas I. Mueller, "A Contribution to the Empirics of Reservation Wages," American Economic Journal: Economic Policy, February 2016, 8 (1), 142-179.

Le Barbanchon, Thomas, Roland Rathelot, and Alexandra Roulet, "Unemployment Insurance and Reservation Wages: Evidence from Administrative Data," Journal of Public Economics, forthcoming.

Leung, Pauline and Christopher J. O'Leary, "Should UI Eligibility Be Expanded to Low-Earning Workers? Evidence on Employment, Transfer Receipt, and Income from Administrative Data," 2015. Upjohn Institute Working Paper 15-236.

Manning, Alan, "Imperfect Competition in the Labor Market," Handbook of Labor Economics, 2011, 4, 973-1041.

Mas, Alexandre and Amanda Pallais, "Valuing Alternative Work Arrangements," American Economic Review, forthcoming.

Mortensen, Dale T., "Job Search and Labor Market Analysis," in O. Ashenfelter and R. Layard, eds., Handbook of Labor Economics, Vol. 2, Elsevier, 1987, chapter 15, pp. 849-919.

- and Christopher A. Pissarides, "Job creation and job destruction in the theory of unemployment," Review of Economic Studies, 1994, 61 (3), 397-415.

- and Eva Nagypal, "More on Unemployment and Vacancy Fluctuations," Review of Economic Dynamics, 2007, 10 (3), 327-347.

Oettinger, Gerald S., "An Empirical Analysis of the Daily Labor Supply of Stadium Vendors," Journal of Political Economy, April 1999, 107 (2), 360-392. 
Robinson, Joan, The Economics of Imperfect Competition, Springer, 1969.

Shimer, Robert, "The Cyclical Behavior of Equilibrium Unemployment and Vacancies," American Economic Review, March 2005, 95 (1), 25-49.

Small, Kenneth A., "Valuation of Travel Time," Economics of Transportation, 2012, 1 (1), 2-14.

Stafford, Tess M., "What Do Fishermen Tell Us That Taxi Drivers Do Not? An Empirical Investigation of Labor Supply," Journal of Labor Economics, July 2015, 33 (3), 683-710. 


\section{Figure 1. Marginal Value of Time Unemployed Applicants}

5 vs. 10 Hours

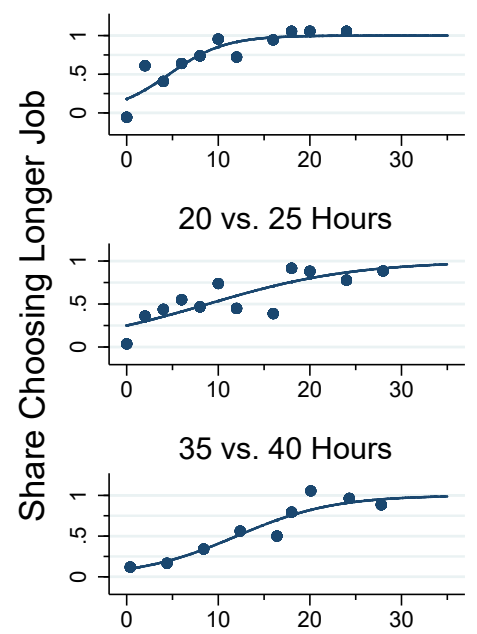

10 vs. 15 Hours

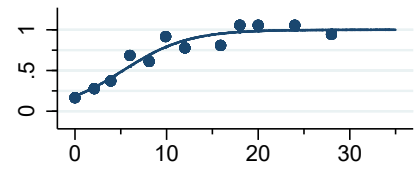

25 vs. 30 Hours

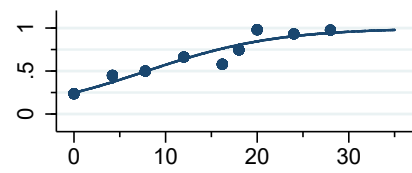

40 vs. 45 Hours

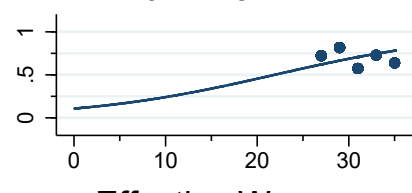

15 vs. 20 Hours

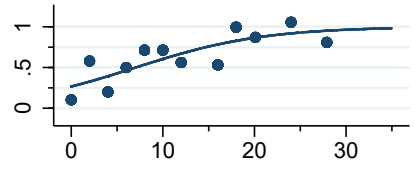

30 vs. 35 Hours

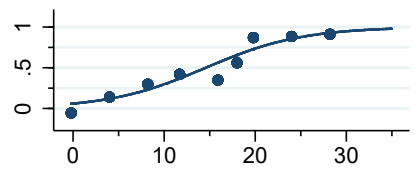

45 vs. 50 Hours

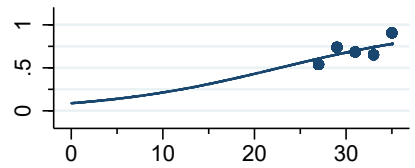

Effective Wage

Notes: Applicants chose between two jobs with different hours per week and hourly wages. Each panel shows results from a different choice. The points show the inattention-corrected fraction of applicants who chose the longer job at each effective wage (calculated as described in the text). Due to the inattention correction, these 'shares' can be below zero or above one. The maximum likelihood fit is estimated off the individual-level data, correcting for applicant inattention as described in the text.

Figure 2. Labor Supply Function Unemployed Applicants

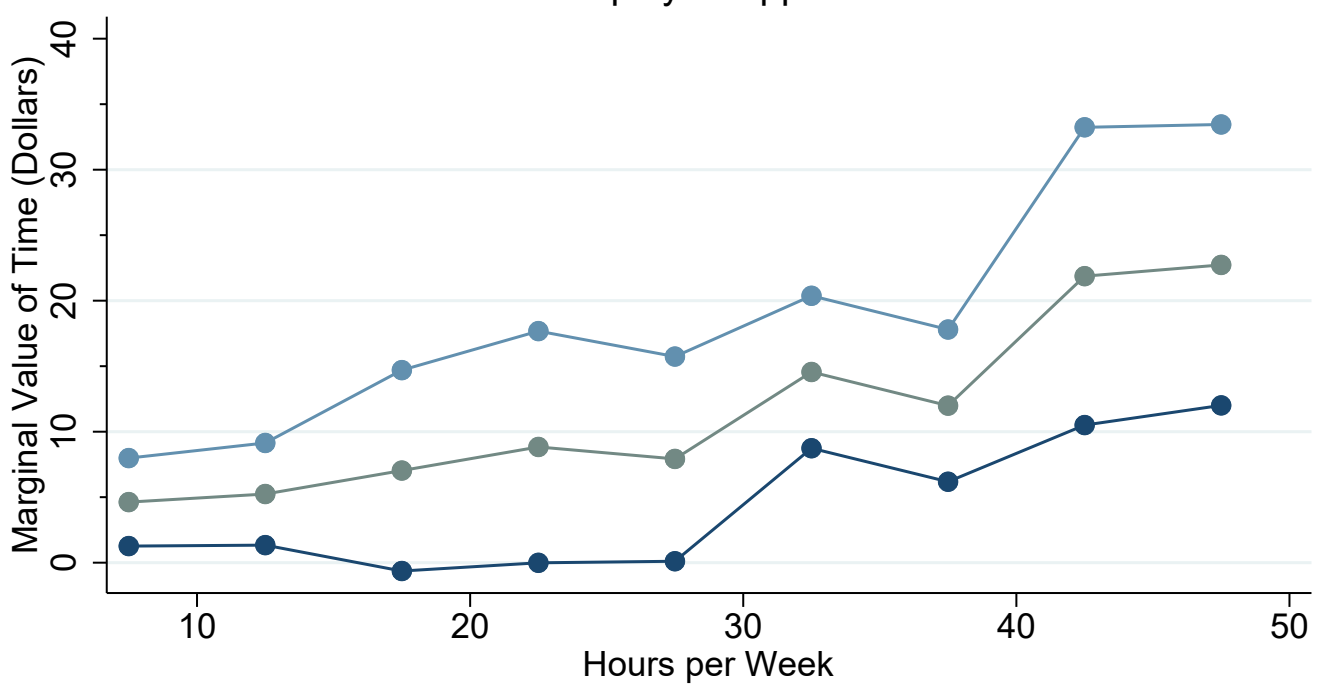

- 25th Percentile $\bullet$ 50th Percentile $\bullet$ 75th Percentile

Notes: The figure shows the 25th, 50th, and 75th percentile marginal value of time estimates from each hours choice in the experiment. Estimates are connected with linear segments. Only unemployed applicants are included. 
Figure 3. Labor Supply Elasticity

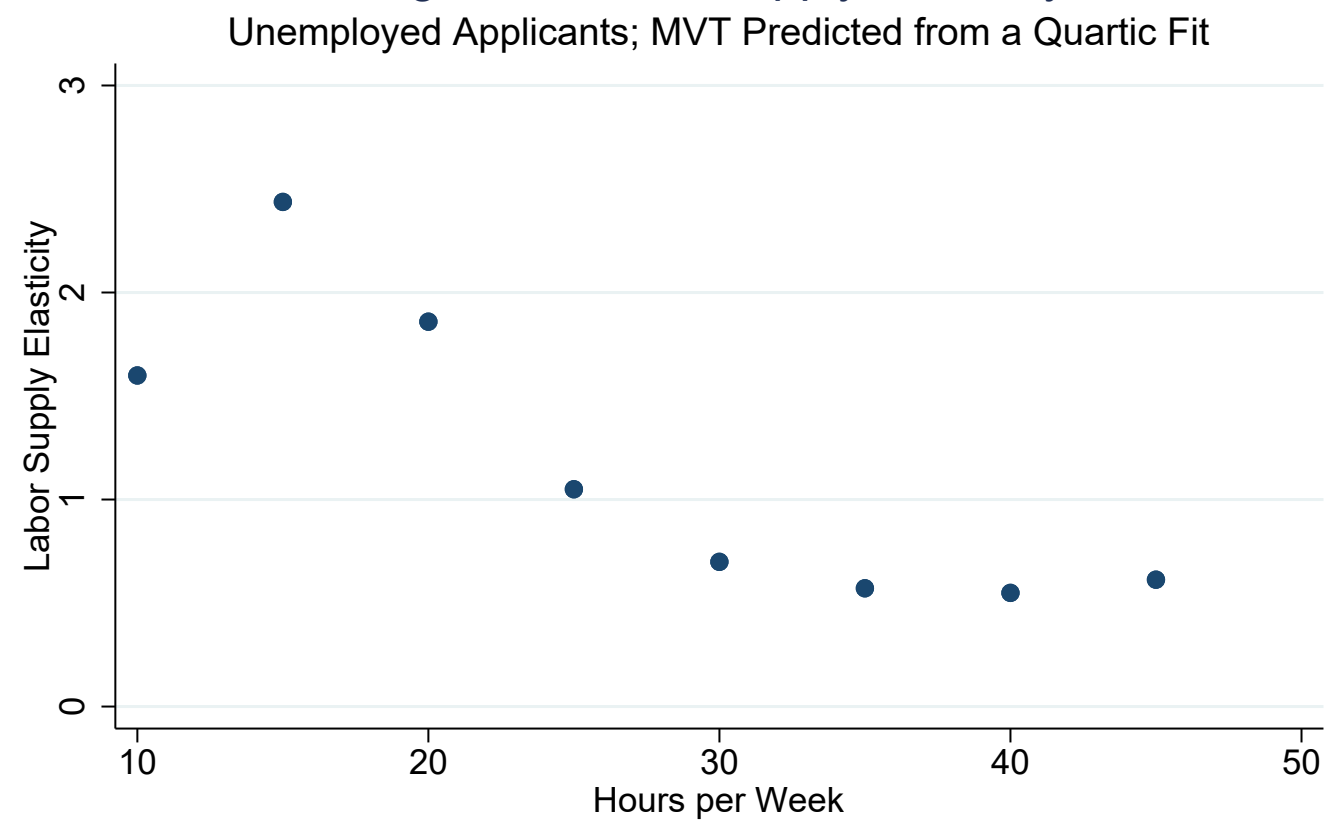

Notes: A quartic function was fit to the labor supply curve in Figure 2. The figure shows the labor supply elasticities calculated from the mean value of time as predicted from this function.

Figure 4. Smoothed Labor Supply Curve Unemployed Applicants; Quartic Fit

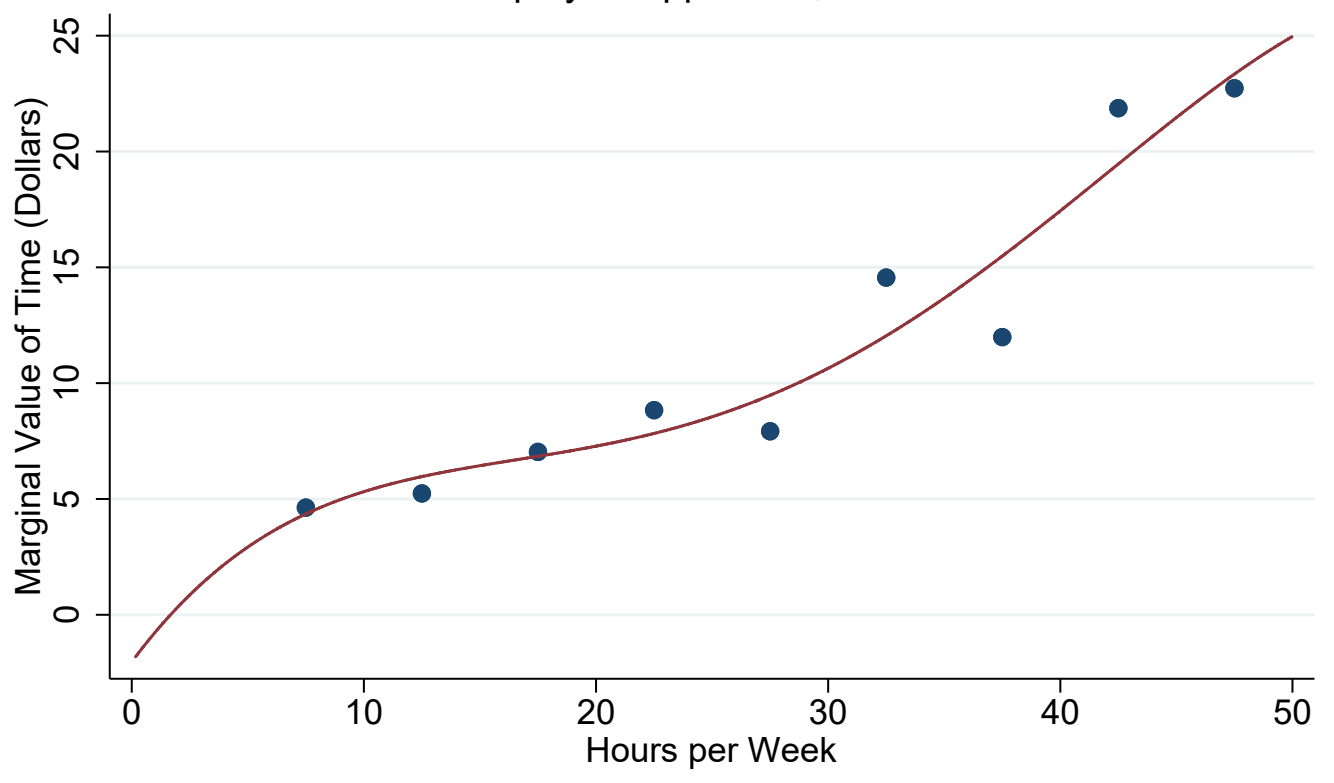

Notes: The figure plots the mean MVT for unemployed applicants in each hours choice. The points are overlaid by a quartic polynomial estimated off of these points. 
Table 1. Descriptive Statistics

\begin{tabular}{|c|c|c|c|c|}
\hline & \multicolumn{2}{|c|}{ Experiment } & \multicolumn{2}{|c|}{ CPS } \\
\hline & All & Unemployed Applicants & All & $\begin{array}{c}\text { Phone Survey and Data } \\
\text { Entry Workers }\end{array}$ \\
\hline Female & $83 \%$ & $83 \%$ & $51 \%$ & $67 \%$ \\
\hline Currently Employed & $41 \%$ & $0 \%$ & $95 \%$ & $100 \%$ \\
\hline Full-time & $14 \%$ & $0 \%$ & $79 \%$ & $81 \%$ \\
\hline Part-time & $28 \%$ & $0 \%$ & $16 \%$ & $19 \%$ \\
\hline Unemployed & $59 \%$ & $100 \%$ & $5 \%$ & $0 \%$ \\
\hline Unemployed for $<3$ Months & $37 \%$ & $64 \%$ & & \\
\hline Unemployed for 3-6 Months & $7 \%$ & $13 \%$ & & \\
\hline Unemployed for $>6$ Months & $14 \%$ & $23 \%$ & & \\
\hline \multicolumn{5}{|l|}{ Age } \\
\hline Average Age & 33.6 & 32.7 & 39.8 & 37.0 \\
\hline$<30$ years old & $46 \%$ & $49 \%$ & $30 \%$ & $37 \%$ \\
\hline $30-40$ years old & $30 \%$ & $30 \%$ & $22 \%$ & $24 \%$ \\
\hline$>40$ years old & $24 \%$ & $21 \%$ & $48 \%$ & $39 \%$ \\
\hline \multicolumn{5}{|l|}{ Education } \\
\hline Less than High School & $2 \%$ & $2 \%$ & $14 \%$ & $6 \%$ \\
\hline High School & $27 \%$ & $30 \%$ & $27 \%$ & $30 \%$ \\
\hline Some College & $44 \%$ & $44 \%$ & $19 \%$ & $29 \%$ \\
\hline College Degree & $24 \%$ & $21 \%$ & $29 \%$ & $31 \%$ \\
\hline Advanced Degree & $4 \%$ & $2 \%$ & $10 \%$ & $4 \%$ \\
\hline \multicolumn{5}{|l|}{ Race } \\
\hline White & $45 \%$ & $44 \%$ & $61 \%$ & $57 \%$ \\
\hline Black & $34 \%$ & $34 \%$ & $13 \%$ & $16 \%$ \\
\hline Hispanic & $11 \%$ & $12 \%$ & $18 \%$ & $19 \%$ \\
\hline Other & $9 \%$ & $10 \%$ & $9 \%$ & $8 \%$ \\
\hline Observations & 2,658 & 1,152 & 248,596 & 3,542 \\
\hline
\end{tabular}

Notes: The first column of data presents descriptive statistics on the entire experiment sample, while the second column focuses on unemployed applicants. The third column presents statistics on respondents ages 16 to 64 in the 2016 CPS Merged Outgoing Rotation Groups (MORGs), while the final column includes only CPS respondents in phone survey occupations (telemarketers, bill and account collectors, customer service representatives, and interviewers, except eligibility and loan) and data entry keyers, where observations on workers in phone survey and data entry occupations are weighted by the prevalence of each position in the experiment. 
Table 2. Randomization Assessment p-Values from Regressions of Covariates on Effective Wage Dummies

\begin{tabular}{|c|c|c|c|c|c|c|c|c|c|}
\hline & 5 vs. 10 & 10 vs. 15 & 15 vs. 20 & 20 vs. 25 & 25 vs. 30 & 30 vs. 35 & 35 vs. 40 & 40 vs. 45 & 45 vs. 50 \\
\hline Age & 0.79 & 0.83 & 0.95 & 0.51 & 0.72 & 0.78 & 0.19 & 0.69 & 0.47 \\
\hline Female & 0.94 & 0.11 & 0.14 & 0.85 & 0.50 & 0.21 & 0.58 & 0.70 & 0.43 \\
\hline White & 0.51 & 0.61 & 0.98 & 0.83 & 0.95 & 0.53 & 0.84 & 0.02 & 0.95 \\
\hline Black & 0.75 & 0.77 & 0.62 & 0.91 & 0.37 & 0.01 & 0.42 & 0.28 & 0.47 \\
\hline Hispanic & 0.30 & 0.89 & 0.72 & 0.83 & 0.03 & 0.77 & 0.14 & 0.38 & 0.18 \\
\hline Other Race & 0.15 & 0.44 & 0.79 & 0.40 & 0.78 & 0.21 & 0.54 & 0.01 & 0.84 \\
\hline Applicants in Treatment & 304 & 305 & 323 & 292 & 305 & 319 & 272 & 272 & 266 \\
\hline
\end{tabular}


Table 3. Marginal Value of Time

Unemployed Applicants

\begin{tabular}{|c|c|c|c|c|c|c|}
\hline & & & & Quantiles & & \\
\hline & Mean & $\begin{array}{l}\text { Standard } \\
\text { Deviation }\end{array}$ & 25 th & 50th & 75th & $\mathrm{N}$ \\
\hline 5 vs. 10 Hours & $\$ 4.63$ & $\$ 5.54$ & $\$ 1.27$ & $\$ 4.63$ & $\$ 7.99$ & 117 \\
\hline & $(0.95)$ & (1.33) & (1.24) & $(0.95)$ & $(1.25)$ & \\
\hline 10 vs. 15 Hours & $\$ 5.24$ & $\$ 6.43$ & $\$ 1.34$ & $\$ 5.24$ & $\$ 9.14$ & 124 \\
\hline & $(1.05)$ & (1.58) & $(1.50)$ & $(1.05)$ & $(1.35)$ & \\
\hline 15 vs. 20 Hours & $\$ 7.03$ & $\$ 12.65$ & $-\$ 0.63$ & $\$ 7.03$ & $\$ 14.70$ & 128 \\
\hline & $(1.77)$ & (3.53) & $(3.24)$ & $(1.77)$ & $(2.21)$ & \\
\hline 20 vs. 25 Hours & $\$ 8.84$ & $\$ 14.59$ & $-\$ 0.01$ & $\$ 8.84$ & $\$ 17.68$ & 153 \\
\hline & $(1.72)$ & (3.36) & $(2.88)$ & $(1.72)$ & $(2.43)$ & \\
\hline 25 vs. 30 Hours & $\$ 7.92$ & $\$ 12.89$ & $\$ 0.11$ & $\$ 7.92$ & $\$ 15.74$ & 135 \\
\hline & $(1.85)$ & $(2.81)$ & (2.97) & $(1.85)$ & $(1.95)$ & \\
\hline 30 vs. 35 Hours & $\$ 14.56$ & $\$ 9.60$ & $\$ 8.74$ & $\$ 14.56$ & $\$ 20.38$ & 133 \\
\hline & $(1.40)$ & $(1.82)$ & (1.71) & $(1.40)$ & $(1.85)$ & \\
\hline 35 vs. 40 Hours & $\$ 11.99$ & $\$ 9.59$ & $\$ 6.18$ & $\$ 11.99$ & $\$ 17.80$ & 112 \\
\hline & $(1.53)$ & $(2.29)$ & $(2.23)$ & $(1.53)$ & $(1.88)$ & \\
\hline 40 vs. 45 Hours & $\$ 21.87$ & $\$ 18.75$ & $\$ 10.51$ & $\$ 21.87$ & $\$ 33.23$ & 121 \\
\hline & $(1.75)$ & $(1.50)$ & $(0.84)$ & $(1.75)$ & $(2.66)$ & \\
\hline 45 vs. 50 Hours & $\$ 22.73$ & $\$ 17.69$ & $\$ 12.01$ & $\$ 22.73$ & $\$ 33.45$ & 129 \\
\hline & $(1.57)$ & $(1.22)$ & $(0.83)$ & $(1.57)$ & $(2.31)$ & \\
\hline Implied $\tilde{z}$ & 0.58 & & & 0.58 & & 902 \\
\hline & $(0.04)$ & & & $(0.04)$ & & \\
\hline
\end{tabular}

Notes: The table provides statistics on workers' marginal value of time in each hours range. Estimates are limited to applicants who are unemployed and are derived from an inattention-corrected maximum likelihood model described in the text. Robust standard errors calculated using the delta method are in parentheses. The implied $\tilde{z}$ estimate is based on hours up to 40 . 
Table 4. Marginal Value of Time: Robustness to Reweighting Unemployed Applicants

\begin{tabular}{|c|c|c|c|c|c|c|c|c|c|c|c|c|}
\hline & & A. Weight & ing Pre-Ex & ment Cha & teristics & & & & ghts using & Characteri & & \\
\hline & & & & Quantiles & & & & & & Quantiles & & \\
\hline & Mean & $\begin{array}{l}\text { Standard } \\
\text { Deviation }\end{array}$ & 25th & 50th & 75th & $\mathrm{N}$ & Mean & $\begin{array}{l}\text { Standard } \\
\text { Deviation }\end{array}$ & 25th & 50th & 75th & $\mathrm{N}$ \\
\hline 5 vs 10 Hours & $\begin{array}{l}\$ 6.00 \\
(1.29)\end{array}$ & $\begin{array}{l}\$ 4.09 \\
(1.11)\end{array}$ & $\begin{array}{l}\$ 3.52 \\
(1.52)\end{array}$ & $\begin{array}{l}\$ 6.00 \\
(1.29)\end{array}$ & $\begin{array}{l}\$ 8.47 \\
(1.38)\end{array}$ & 94 & $\begin{array}{l}\$ 5.21 \\
(1.09)\end{array}$ & $\begin{array}{l}\$ 3.84 \\
(0.88)\end{array}$ & $\begin{array}{l}\$ 2.88 \\
(1.31)\end{array}$ & $\begin{array}{l}\$ 5.21 \\
(1.09)\end{array}$ & $\begin{array}{l}\$ 7.54 \\
(1.10)\end{array}$ & 94 \\
\hline 10 vs 15 Hours & $\begin{array}{l}\$ 6.65 \\
(1.15)\end{array}$ & $\begin{array}{l}\$ 3.50 \\
(1.24)\end{array}$ & $\begin{array}{l}\$ 4.53 \\
(1.20)\end{array}$ & $\begin{array}{l}\$ 6.65 \\
(1.15)\end{array}$ & $\begin{array}{l}\$ 8.77 \\
(1.53)\end{array}$ & 99 & $\begin{array}{l}\$ 7.33 \\
(1.01)\end{array}$ & $\begin{array}{l}\$ 3.46 \\
(0.81)\end{array}$ & $\begin{array}{l}\$ 5.23 \\
(1.13)\end{array}$ & $\begin{array}{l}\$ 7.33 \\
(1.01)\end{array}$ & $\begin{array}{l}\$ 9.43 \\
(1.12)\end{array}$ & 99 \\
\hline 15 vs 20 Hours & $\begin{array}{l}\$ 5.29 \\
(6.07)\end{array}$ & $\begin{array}{l}\$ 26.09 \\
(23.10)\end{array}$ & $\begin{array}{l}-\$ 10.53 \\
(18.46)\end{array}$ & $\begin{array}{l}\$ 5.29 \\
(6.07)\end{array}$ & $\begin{array}{l}\$ 21.10 \\
(11.16)\end{array}$ & 108 & $\begin{array}{l}\$ 6.06 \\
(4.42)\end{array}$ & $\begin{array}{l}\$ 20.75 \\
(17.47)\end{array}$ & $\begin{array}{c}-\$ 6.51 \\
(13.50)\end{array}$ & $\begin{array}{l}\$ 6.06 \\
(4.42)\end{array}$ & $\begin{array}{l}\$ 18.63 \\
(8.99)\end{array}$ & 108 \\
\hline 20 vs 25 Hours & $\begin{array}{l}\$ 8.25 \\
(3.40)\end{array}$ & $\begin{array}{l}\$ 17.47 \\
(7.42)\end{array}$ & $\begin{array}{l}-\$ 2.34 \\
(6.46)\end{array}$ & $\begin{array}{l}\$ 8.25 \\
(3.40)\end{array}$ & $\begin{array}{c}\$ 18.84 \\
(4.68)\end{array}$ & 125 & $\begin{array}{c}\$ 10.33 \\
(4.41)\end{array}$ & $\begin{array}{l}\$ 24.04 \\
(13.01)\end{array}$ & $\begin{array}{l}-\$ 4.23 \\
(9.67)\end{array}$ & $\begin{array}{l}\$ 10.33 \\
(4.41)\end{array}$ & $\begin{array}{l}\$ 24.90 \\
(8.35)\end{array}$ & 125 \\
\hline 25 vs 30 Hours & $\begin{array}{l}\$ 8.84 \\
(2.15)\end{array}$ & $\begin{array}{l}\$ 10.27 \\
(3.22)\end{array}$ & $\begin{array}{l}\$ 2.61 \\
(3.33)\end{array}$ & $\begin{array}{l}\$ 8.84 \\
(2.15)\end{array}$ & $\begin{array}{c}\$ 15.06 \\
(2.40)\end{array}$ & 110 & $\begin{array}{c}\$ 10.68 \\
(1.87)\end{array}$ & $\begin{array}{l}\$ 9.37 \\
(2.81)\end{array}$ & $\begin{array}{l}\$ 5.00 \\
(2.88)\end{array}$ & $\begin{array}{c}\$ 10.68 \\
(1.87)\end{array}$ & $\begin{array}{l}\$ 16.35 \\
(2.11)\end{array}$ & 110 \\
\hline 30 vs 35 Hours & $\begin{array}{c}\$ 16.71 \\
(1.86)\end{array}$ & $\begin{array}{l}\$ 6.15 \\
(2.02)\end{array}$ & $\begin{array}{c}\$ 12.98 \\
(1.92)\end{array}$ & $\begin{array}{c}\$ 16.71 \\
(1.86)\end{array}$ & $\begin{array}{c}\$ 20.44 \\
(2.49)\end{array}$ & 102 & $\begin{array}{c}\$ 16.99 \\
(2.44)\end{array}$ & $\begin{array}{l}\$ 6.99 \\
(2.36)\end{array}$ & $\begin{array}{l}\$ 12.76 \\
(1.94)\end{array}$ & $\begin{array}{c}\$ 16.99 \\
(2.44)\end{array}$ & $\begin{array}{l}\$ 21.23 \\
(3.50)\end{array}$ & 102 \\
\hline 35 vs 40 Hours & $\begin{array}{c}\$ 14.20 \\
(1.67)\end{array}$ & $\begin{array}{l}\$ 5.46 \\
(1.24)\end{array}$ & $\begin{array}{c}\$ 10.89 \\
(1.75)\end{array}$ & $\begin{array}{c}\$ 14.20 \\
(1.67)\end{array}$ & $\begin{array}{c}\$ 17.50 \\
(1.90)\end{array}$ & 88 & $\begin{array}{c}\$ 14.53 \\
(1.93)\end{array}$ & $\begin{array}{l}\$ 5.94 \\
(1.37)\end{array}$ & $\begin{array}{l}\$ 10.93 \\
(2.09)\end{array}$ & $\begin{array}{c}\$ 14.53 \\
(1.93)\end{array}$ & $\begin{array}{l}\$ 18.12 \\
(2.12)\end{array}$ & 88 \\
\hline 40 vs 45 Hours & $\begin{array}{c}\$ 20.01 \\
(1.96)\end{array}$ & $\begin{array}{l}\$ 14.63 \\
(1.43)\end{array}$ & $\begin{array}{c}\$ 11.15 \\
(1.09)\end{array}$ & $\begin{array}{c}\$ 20.01 \\
(1.96)\end{array}$ & $\begin{array}{c}\$ 28.88 \\
(2.82)\end{array}$ & 97 & $\begin{array}{c}\$ 21.61 \\
(2.17)\end{array}$ & $\begin{array}{l}\$ 14.54 \\
(1.46)\end{array}$ & $\begin{array}{l}\$ 12.79 \\
(1.28)\end{array}$ & $\begin{array}{c}\$ 21.61 \\
(2.17)\end{array}$ & $\begin{array}{l}\$ 30.42 \\
(3.05)\end{array}$ & 97 \\
\hline 45 vs 50 Hours & $\begin{array}{c}\$ 22.11 \\
(2.06)\end{array}$ & $\begin{array}{l}\$ 14.67 \\
(1.36)\end{array}$ & $\begin{array}{c}\$ 13.22 \\
(1.23)\end{array}$ & $\begin{array}{c}\$ 22.11 \\
(2.06)\end{array}$ & $\begin{array}{c}\$ 30.99 \\
(2.88)\end{array}$ & 99 & $\begin{array}{c}\$ 23.35 \\
(2.21)\end{array}$ & $\begin{array}{l}\$ 13.99 \\
(1.32)\end{array}$ & $\begin{array}{l}\$ 14.87 \\
(1.41)\end{array}$ & $\begin{array}{c}\$ 23.35 \\
(2.21)\end{array}$ & $\begin{array}{l}\$ 31.83 \\
(3.01)\end{array}$ & 99 \\
\hline Implied $\tilde{z}$ & $\begin{array}{c}0.57 \\
(0.07)\end{array}$ & & & $\begin{array}{c}0.57 \\
(0.07)\end{array}$ & & 726 & $\begin{array}{c}0.62 \\
(0.07)\end{array}$ & & & $\begin{array}{c}0.62 \\
(0.07)\end{array}$ & & 726 \\
\hline
\end{tabular}


Table 5. Labor Supply Elasticities Unemployed Applicants

\begin{tabular}{|c|c|c|c|c|}
\hline & Raw Points & Quadratic & Quartic & Spline \\
\hline 10 Hours & 4.02 & 6.08 & 1.60 & 1.24 \\
\hline 15 Hours & 1.14 & 2.03 & 2.44 & 1.16 \\
\hline 20 Hours & 1.10 & 1.18 & 1.86 & 1.12 \\
\hline 25 Hours & -1.84 & 0.87 & 1.05 & 1.10 \\
\hline 30 Hours & 0.28 & 0.72 & 0.70 & 1.08 \\
\hline 35 Hours & -0.74 & 0.64 & 0.57 & 1.07 \\
\hline 40 Hours & 0.21 & 0.60 & 0.55 & 0.53 \\
\hline 45 Hours & 2.88 & 0.57 & 0.61 & 0.40 \\
\hline RMSE & & 2.24 & 2.68 & 2.38 \\
\hline \multicolumn{5}{|c|}{$\begin{array}{l}\text { Notes: The columns show estimates of labor supply elasticities at different } \\
\text { hours per week. Points in the first column are calculated from the mean } \\
\text { MVT at each hours choice from the experiment (e.g., the } 25 \text { hours } \\
\text { estimate is created from the MVTs at } 20-25 \text { hours and } 25-30 \text { hours). The } \\
\text { remaining columns fit a curve to the MVT points and use this curve to } \\
\text { calculate labor supply elasticities. The fitted curves use a quadratic, } \\
\text { quartic, and spline with a knot at } 40 \text { hours per week, respectively. The final } \\
\text { row shows the root mean squared error for each of the fits. Only } \\
\text { unemployed applicants are included. }\end{array}$} \\
\hline
\end{tabular}




\begin{tabular}{l} 
All Applicants \\
\cline { 2 - 7 }
\end{tabular}


Table 7. Heterogeneity by Predicted Market Wage and Local Labor Market Conditions

Unemployed Applicants

\begin{tabular}{cc} 
Mean $\quad$ Mean + 1 SD & Mean - 1 SD \\
Valference Between \\
and (Mean - 1 SD) \\
\hline
\end{tabular}

Mean Value of Time

Implied $\tilde{z}$

0.57

(0.04)

Implied $\tilde{z}$

0.57

0.57
$(0.04)$

$\$ 7.99$

(0.59)$$
\text { (0.04) }
$$

\section{A. Predicted Wage}

Mean (\$13.93), Standard Deviation (\$3.82)

$\$ 9.06 \quad \$ 6.96$

(0.82)

\$2.10*

\section{B. Local Unemployment Rate} Mean (4.43\%), Standard Deviation (0.81\%)

$\begin{array}{ccc}0.59 & 0.56 & 0.03 \\ (0.05) & (0.06) & (0.08)\end{array}$

C. Local Unemployment Relative to $10-$ Year Historical Mean Mean (-2.64\%), Standard Deviation (1.11\%)

Notes: The table shows results obtained by fitting a stacked maximum likelihood model with additional covariates as described in the text. Each panel presents the mean value of time or implied $\tilde{z}$ associated with the mean value, mean value plus one standard deviation, and mean value minus one standard deviation of the covariate (predicted wage, local unemployment rate, or local unemployment rate relative to the 10-year historical mean). Local unemployment rates from the BLS's Local Area Unemployment Statistics program are at the MSA-level and are unadjusted in Panel B and seasonally adjusted in Panel C. Panel C uses monthly unemployment rates from April 2007 to March 2017 to calculate the historical mean. Robust standard errors calculated using the delta method are in parentheses. Standard errors in Panels B and C are clustered by MSA. 


\section{Appendix A. UAS Survey Details}

The Understanding American Study (UAS) Survey 79 was distributed by the University of Southern California Center for Economic and Social Research (CESR) to 5,812 people in their nationally-representative panel of respondents who speak English and had completed a background survey. The survey was in the field from December 15, 2016 until February 7, 2017, and 74\% of the invited panel participants completed the survey. Respondents were compensated $\$ 3$ for the survey, which averaged 4 minutes.

Respondents were asked for their labor force status and were then routed to corresponding sections of the survey. All respondents were asked the easiest way to report their earnings (hourly, weekly, etc.) at their main or last job, and how much they typically earn(ed) at their main or last job in that pay period.

Employed and unemployed respondents then saw a series of vignettes that paired two hypothetical jobs which differed only in the number of hours per week and their wages. (See the text for details.) Before proceeding to the next vignette, respondents chose the job that they would prefer. The (randomized) wages in these vignettes were percentage multiples of their current or previous wage, entered earlier in the survey.

Respondents were also asked to choose between two jobs which required the same number of hours per week but offered different wages. The inattention rate used in the regressions for UAS respondents is double the fraction of individuals choosing the lower-paying option.

The remainder of the survey asked about respondents' marital status, parental status, and any partner's/spouse's labor supply behavior.

The estimate for $\widetilde{z}$ presented in the text is based on a sample of respondents who are in the labor force and reported their pay hourly. This includes 2,354 choices made by 785 people. The average wage presented uses this sample excluding wages above $\$ 99.99 /$ hour. The exclusion affects 78 people (another 3 did not report wages). 
Appendix Figure 1. Job Advertisement

[center] [Phone Survey Associate / Data Entry Associate] ([city, state])

[center] is currently recruiting [phone survey interviewers / data entry associates].

This is not a sales or telemarketing position.

Please follow the link [link] to apply to this opportunity. We do not accept applications through email.

Essential Functions

[ Make phone calls in order to implement phone surveys / Accurately and quickly perform data entry tasks ]

Desired Skills

Good communication skills

Ability to work with others

Used to basic computer and/or mobile applications

- Principals only. Recruiters, please don't contact this job poster.

- do NOT contact us with unsolicited services or offers

compensation: Hourly

employment type: employee's choice

Notes: The name of the center is redacted. 
Appendix Figure 2. Job Description

\section{Job Description}

Tell us which of the following two positions you prefer. The type of work is the same in both jobs. Please click on each job title in order to review the work descriptions.

It is important that you read the position descriptions carefully so you can indicate your preference below.

\section{Positions}

\section{Phone Survey Associate Position \#104 (click for description)}

This is a one-month work-from-home phone survey position.

The position is 25 hours per week.

This position pays 15.60 dollars per hour.

\section{Phone Survey Associate Position \#126 (click for description)}

This is a one-month work-from-home phone survey position.

The position is 20 hours per week.

This position pays 18.00 dollars per hour.

If you were selected for both positions, which one would you prefer? Write your preferred position in the box below. If you are hired, we will offer you your choice. Your choice will not affect whether you receive a job offer. It will only be reviewed after hiring decisions have been made. If there are other open positions at_you will also be considered for those. If you are not interested in applying, simply click on "No thanks, this isn't for me".

Notes: Here, the name of the center is redacted. 


\section{Appendix Figure 3. Probability of Choosing \\ a Job Option by Effective Wage \\ All Experiment Applicants}

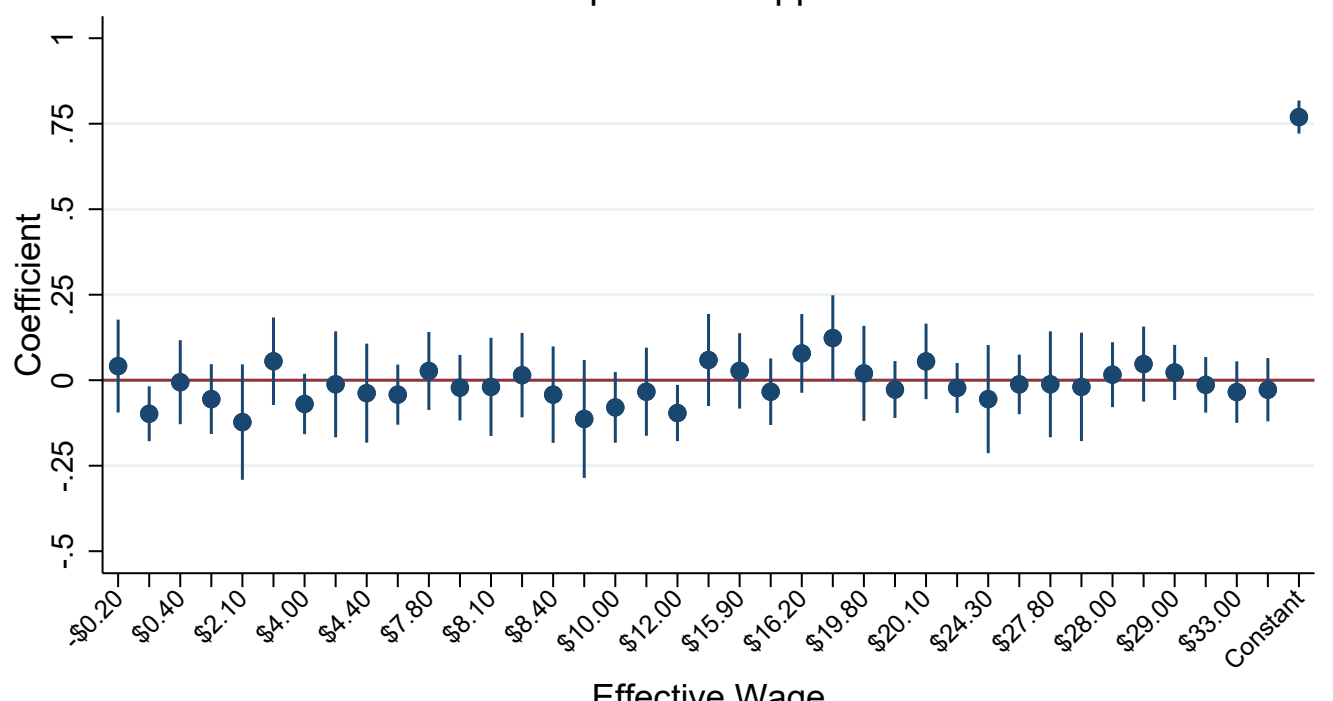

\section{Effective Wage}

Notes: The figure plots the coefficients from a regression of an indicator for choosing one of the two job options on (non-rounded) effective wage dummies. Applicants are included if they were presented with the job options. The omitted category is an $\$ 18$ effective wage. Vertical bars show $95 \%$ confidence intervals.

\section{Appendix Figure 4. Probability of Submitting Subsequent Demographic Information by Effective Wage}

All Experiment Applicants

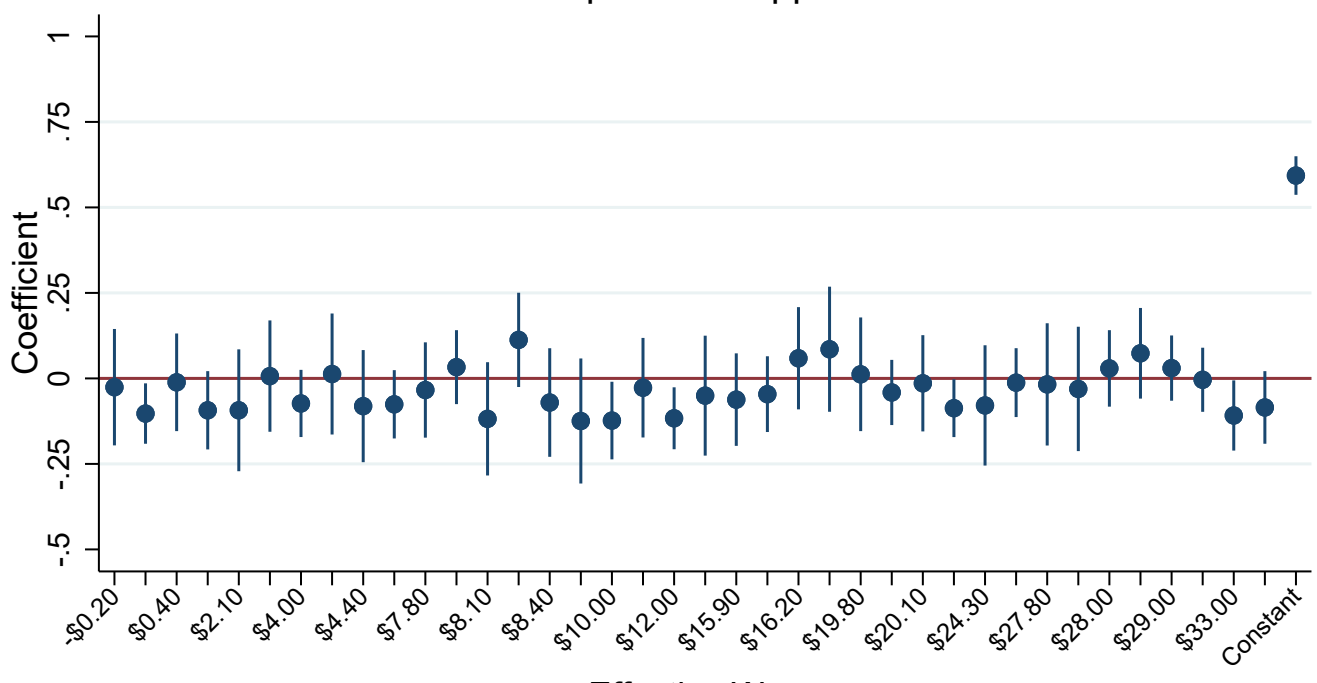

Effective Wage

Notes: The figure plots the coefficients from a regression of an indicator for submitting the demographic information after the job choice on (non-rounded) effective wage dummies. Applicants are included if they were presented with the job options. The omitted category is an $\$ 18$ effective wage. Vertical bars show $95 \%$ confidence intervals. 
Appendix Figure 5. Marginal Value of Time Unemployed Applicants; Uncorrected for Inattention
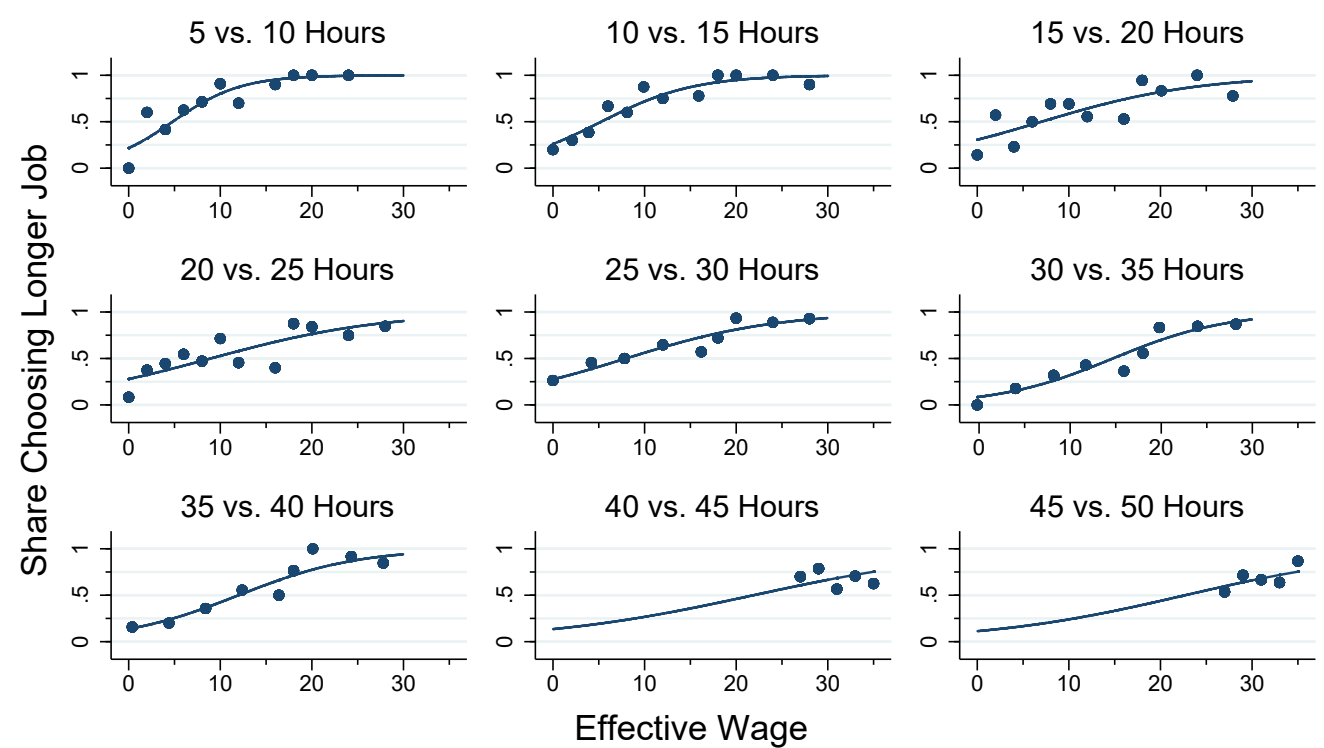

Notes: Applicants chose between two jobs with different hours per week and hourly wages. Each panel shows results from a different choice. The points show the raw fraction of applicants who chose the longer job at each effective wage. The maximum likelihood fit is estimated off the individual-level data as described in the text, without correcting for inattention.

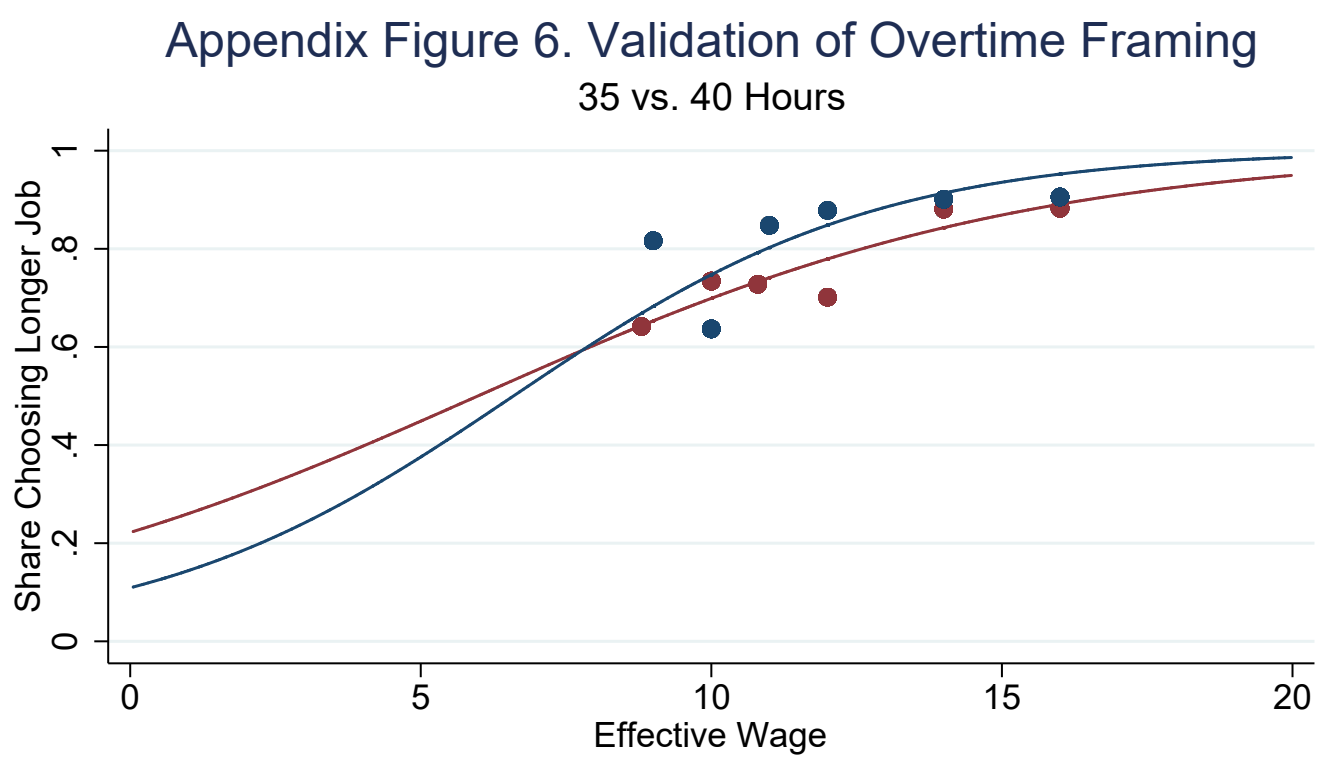

\section{- Traditional Framing • Overtime Framing}

Notes: The figure shows the results from the overtime validation treatment described in the text. In the "traditional framing," the 35 and 40 hour jobs had two separate wage rates. In the "overtime framing," the 35 and 40 hour jobs both paid the same wage up to 35 hours per week. The 40 hour job paid a separate wage for the last five hours (hours over 35 hours per week). All experimental applicants in the overtime validation treatment are included, regardless of their employment status. 


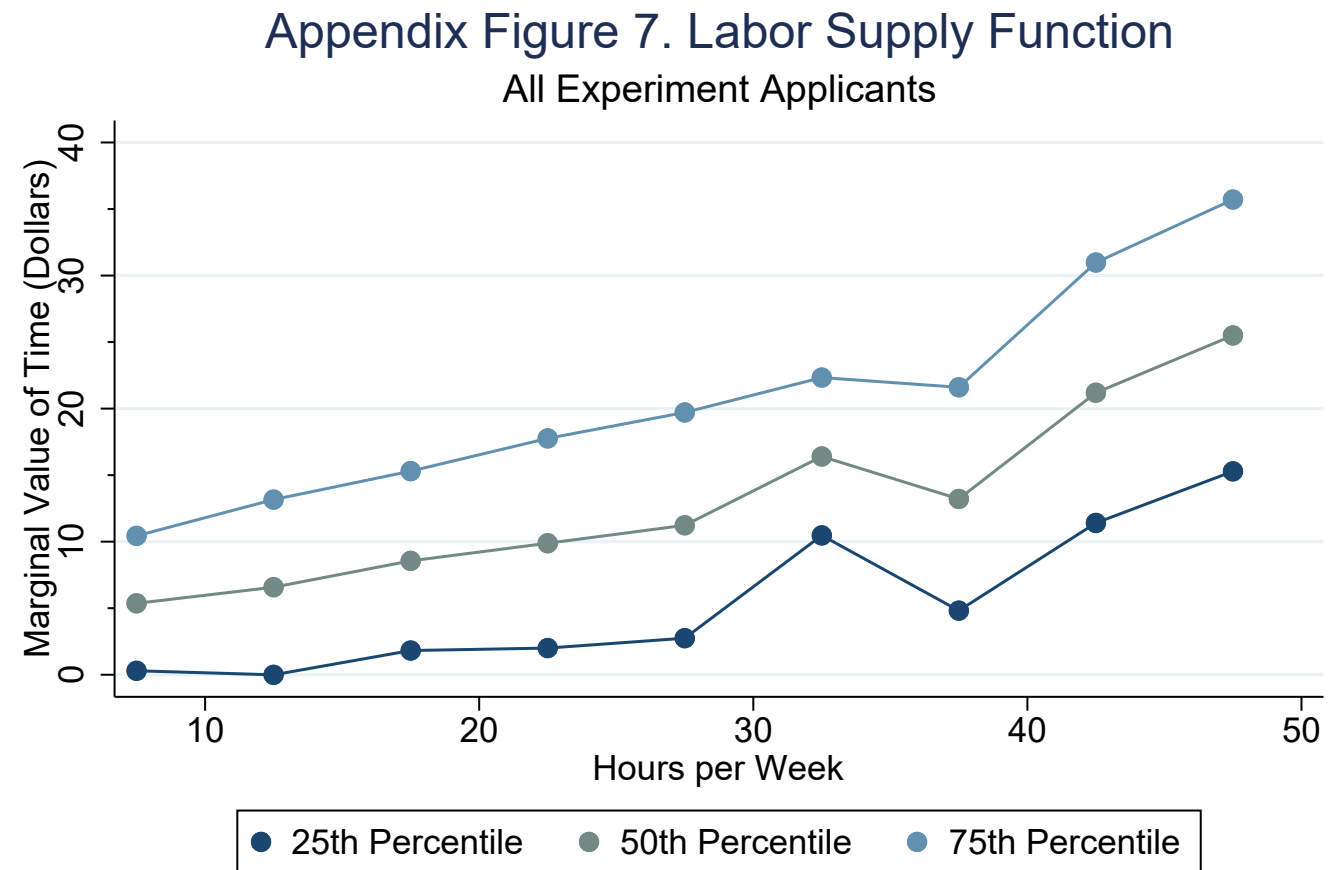

Notes: The figure shows the 25th, 50th, and 75th percentile marginal value of time estimates from each hours choice in the experiment. Estimates are connected with linear segments. Experimental applicants are included regardless of employment status. 
Appendix Table 1. Hourly Wages by Effective Wage

\begin{tabular}{|c|c|c|c|c|c|c|c|c|c|c|c|c|c|c|}
\hline \multirow[b]{2}{*}{ Effective Wage } & \multicolumn{2}{|c|}{$\underline{5 \text { vs. } 10 \text { Hours }}$} & \multicolumn{2}{|c|}{10 vs. 15 Hours } & \multicolumn{2}{|c|}{15 vs. 20 Hours } & \multicolumn{2}{|c|}{20 vs. 25 Hours } & \multicolumn{2}{|c|}{25 vs. 30 Hours } & \multicolumn{2}{|c|}{30 vs. 35 Hours } & \multicolumn{2}{|c|}{35 vs. 40 Hours } \\
\hline & 5 Hours & 10 Hours & 10 Hours & 15 Hours & 15 Hours & 20 Hours & 20 Hours & 25 Hours & 25 Hours & 30 Hours & 30 Hours & 35 Hours & 35 Hours & 40 Hours \\
\hline$\$ 0.00$ & 18.00 & 9.00 & 18.00 & 12.00 & 18.00 & 13.50 & 18.00 & 14.40 & 18.00 & 15.00 & 18.00 & 15.40 & 18.00 & 15.80 \\
\hline$\$ 2.00$ & 18.00 & 10.00 & 18.00 & 12.70 & 18.00 & 14.00 & 18.00 & 14.80 & & & & & & \\
\hline$\$ 4.00$ & 18.00 & 11.00 & 18.00 & 13.30 & 18.00 & 14.50 & 18.00 & 15.20 & 18.00 & 15.70 & 18.00 & 16.00 & 18.00 & 16.30 \\
\hline$\$ 6.00$ & 18.00 & 12.00 & 18.00 & 14.00 & 18.00 & 15.00 & 18.00 & 15.60 & & & & & & \\
\hline$\$ 8.00$ & 18.00 & 13.00 & 18.00 & 14.70 & 18.00 & 15.50 & 18.00 & 16.00 & 18.00 & 16.30 & 18.00 & 16.60 & 18.00 & 16.80 \\
\hline$\$ 10.00$ & 18.00 & 14.00 & 18.00 & 15.30 & 18.00 & 16.00 & 18.00 & 16.40 & & & & & & \\
\hline$\$ 12.00$ & 18.00 & 15.00 & 18.00 & 16.00 & 18.00 & 16.50 & 18.00 & 16.80 & 18.00 & 17.00 & 18.00 & 17.10 & 18.00 & 17.30 \\
\hline$\$ 16.00$ & 18.00 & 17.00 & 18.00 & 17.30 & 18.00 & 17.50 & 18.00 & 17.60 & 18.00 & 17.70 & 18.00 & 17.70 & 18.00 & 17.80 \\
\hline$\$ 18.00$ & 18.00 & 18.00 & 18.00 & 18.00 & 18.00 & 18.00 & 18.00 & 18.00 & 18.00 & 18.00 & 18.00 & 18.00 & 18.00 & 18.00 \\
\hline$\$ 20.00$ & 16.00 & 18.00 & 17.00 & 18.00 & 17.30 & 18.00 & 17.50 & 18.00 & 17.60 & 18.00 & 17.70 & 18.00 & 17.70 & 18.00 \\
\hline$\$ 24.00$ & 12.00 & 18.00 & 15.00 & 18.00 & 16.00 & 18.00 & 16.50 & 18.00 & 16.80 & 18.00 & 17.00 & 18.00 & 17.10 & 18.00 \\
\hline$\$ 28.00$ & & & 13.00 & 18.00 & 14.70 & 18.00 & 15.50 & 18.00 & 16.00 & 18.00 & 16.30 & 18.00 & 16.60 & 18.00 \\
\hline
\end{tabular}

Notes: For each applicant, we randomly selected an hours choice and an effective wage. Each row displays the hourly wages associated with a given effective wage. 
Appendix Table 2. Randomization Assessment: Unemployed Applicants p-Values from Regressions of Covariates on Wage Gap Dummies

\begin{tabular}{|c|c|c|c|c|c|c|c|c|c|}
\hline & 5 vs. 10 & 10 vs. 15 & 15 vs. 20 & 20 vs. 25 & 25 vs. 30 & 30 vs. 35 & 35 vs. 40 & 40 vs. 45 & 45 vs. 50 \\
\hline Age & 0.96 & 0.65 & 0.24 & 0.94 & 0.85 & 0.98 & 0.01 & 0.73 & 0.79 \\
\hline Female & 0.69 & 0.11 & 0.78 & 0.65 & 0.38 & 0.01 & 0.58 & 0.82 & 0.47 \\
\hline White & 0.35 & 0.19 & 0.72 & 0.67 & 0.91 & 0.26 & 0.43 & 0.08 & 0.75 \\
\hline Black & 0.85 & 0.39 & 0.51 & 0.90 & 0.23 & 0.00 & 0.20 & 0.71 & 0.17 \\
\hline Hispanic & 0.45 & 0.82 & 0.62 & 0.47 & 0.25 & 0.41 & 0.59 & 0.86 & 0.04 \\
\hline Other Race & 0.15 & 0.69 & 0.08 & 0.75 & 0.58 & 0.49 & 0.78 & 0.02 & 0.88 \\
\hline Applicants in Treatment & 117 & 124 & 128 & 153 & 135 & 133 & 112 & 121 & 129 \\
\hline
\end{tabular}


Appendix Table 3. Descriptive Statistics by Hours Choice Unemployed Applicants

\begin{tabular}{|c|c|c|c|c|c|c|c|c|c|c|}
\hline & 5 vs. 10 & 10 vs. 15 & 15 vs. 20 & 20 vs. 25 & 25 vs. 30 & 30 vs. 35 & 35 vs. 40 & 40 vs. 45 & 45 vs. 50 & $\begin{array}{l}\mathrm{p} \text {-value of } \\
\text { difference }\end{array}$ \\
\hline Age & 31.9 & 31.8 & 32.2 & 33.2 & 31.9 & 32.7 & 31.0 & 33.9 & 35.3 & 0.097 \\
\hline Number Reporting Age & 116 & 121 & 126 & 150 & 134 & 131 & 108 & 120 & 128 & 1,134 \\
\hline Female & $86.7 \%$ & $80.8 \%$ & $84.8 \%$ & $76.9 \%$ & $85.3 \%$ & $81.8 \%$ & $84.8 \%$ & $83.8 \%$ & $84.1 \%$ & 0.658 \\
\hline Number Reporting Gender & 98 & 104 & 112 & 130 & 116 & 110 & 92 & 99 & 107 & 968 \\
\hline \multicolumn{11}{|l|}{ Race/Ethnicity } \\
\hline White & $42.9 \%$ & $53.8 \%$ & $47.8 \%$ & $43.1 \%$ & $37.4 \%$ & $41.7 \%$ & $45.4 \%$ & $49.0 \%$ & $38.6 \%$ & 0.311 \\
\hline Black & $33.7 \%$ & $28.8 \%$ & $28.7 \%$ & $36.2 \%$ & $36.5 \%$ & $38.0 \%$ & $34.0 \%$ & $31.4 \%$ & $42.6 \%$ & 0.483 \\
\hline Hispanic & $12.2 \%$ & $9.6 \%$ & $14.8 \%$ & $11.5 \%$ & $16.5 \%$ & $13.0 \%$ & $12.4 \%$ & $6.9 \%$ & $6.9 \%$ & 0.353 \\
\hline Other Race & $11.2 \%$ & $7.7 \%$ & $8.7 \%$ & $9.2 \%$ & $9.6 \%$ & $7.4 \%$ & $8.2 \%$ & $12.7 \%$ & $11.9 \%$ & 0.905 \\
\hline Number Reporting Race/Ethnicity & 98 & 104 & 115 & 130 & 115 & 108 & 97 & 102 & 101 & 970 \\
\hline \multicolumn{11}{|l|}{ Education } \\
\hline Less than High School & $4.3 \%$ & $2.4 \%$ & $3.1 \%$ & $2.6 \%$ & $3.0 \%$ & $0.8 \%$ & $1.8 \%$ & $2.5 \%$ & $0.8 \%$ & 0.700 \\
\hline High School & $29.1 \%$ & $39.5 \%$ & $28.9 \%$ & $27.5 \%$ & $32.6 \%$ & $30.1 \%$ & $33.0 \%$ & $32.2 \%$ & $21.7 \%$ & 0.190 \\
\hline Some College & $42.7 \%$ & $33.9 \%$ & $45.3 \%$ & $45.1 \%$ & $53.3 \%$ & $46.6 \%$ & $38.4 \%$ & $45.5 \%$ & $45.7 \%$ & 0.143 \\
\hline College Degree & $23.1 \%$ & $23.4 \%$ & $21.1 \%$ & $23.5 \%$ & $8.9 \%$ & $18.0 \%$ & $23.2 \%$ & $18.2 \%$ & $26.4 \%$ & 0.027 \\
\hline Advanced Degree & $0.9 \%$ & $0.8 \%$ & $1.6 \%$ & $1.3 \%$ & $2.2 \%$ & $4.5 \%$ & $3.6 \%$ & $1.7 \%$ & $5.4 \%$ & 0.148 \\
\hline Number Reporting Education & 117 & 124 & 128 & 153 & 135 & 133 & 112 & 121 & 129 & 1,152 \\
\hline Total Applicants in Regression Sample & 117 & 124 & 128 & 153 & 135 & 133 & 112 & 121 & 129 & 1,152 \\
\hline
\end{tabular}


Appendix Table 4. Marginal Value of Time

Unemployed Applicants; Uncorrected for Inattention

\begin{tabular}{|c|c|c|c|c|c|c|}
\hline & & & & Quantiles & & \\
\hline & Mean & $\begin{array}{l}\text { Standard } \\
\text { Deviation }\end{array}$ & 25th & 50th & 75th & $\mathrm{N}$ \\
\hline 5 vs 10 Hours & $\$ 4.80$ & $\$ 6.76$ & $\$ 0.70$ & $\$ 4.80$ & $\$ 8.89$ & 117 \\
\hline & $(0.96)$ & (1.29) & $(1.35)$ & (0.96) & (1.11) & \\
\hline 10 vs 15 Hours & $\$ 5.27$ & $\$ 9.15$ & $-\$ 0.28$ & $\$ 5.27$ & $\$ 10.81$ & 124 \\
\hline & (1.22) & (2.18) & $(2.08)$ & (1.22) & (1.46) & \\
\hline 15 vs 20 Hours & $\$ 7.00$ & $\$ 15.53$ & $-\$ 2.41$ & $\$ 7.00$ & $\$ 16.41$ & 128 \\
\hline & (1.91) & (4.03) & $(3.74)$ & (1.91) & $(2.30)$ & \\
\hline 20 vs 25 Hours & $\$ 8.95$ & $\$ 17.07$ & $-\$ 1.39$ & $\$ 8.95$ & $\$ 19.29$ & 153 \\
\hline & (1.74) & (3.67) & (3.15) & (1.74) & $(2.46)$ & \\
\hline 25 vs 30 Hours & $\$ 7.97$ & $\$ 14.92$ & $-\$ 1.08$ & $\$ 7.97$ & $\$ 17.01$ & 135 \\
\hline & $(1.84)$ & (3.08) & (3.15) & (1.84) & $(1.96)$ & \\
\hline 30 vs 35 Hours & $\$ 14.68$ & $\$ 11.33$ & $\$ 7.82$ & $\$ 14.68$ & $\$ 21.55$ & 133 \\
\hline & $(1.34)$ & (1.90) & $(1.70)$ & $(1.34)$ & $(1.82)$ & \\
\hline 35 vs 40 Hours & $\$ 12.00$ & $\$ 11.82$ & $\$ 4.84$ & $\$ 12.00$ & $\$ 19.16$ & 112 \\
\hline & $(1.50)$ & $(2.38)$ & $(2.22)$ & $(1.50)$ & $(1.93)$ & \\
\hline 40 vs 45 Hours & $\$ 21.89$ & $\$ 21.36$ & $\$ 8.94$ & $\$ 21.89$ & $\$ 34.83$ & 121 \\
\hline & $(1.70)$ & $(1.66)$ & $(0.69)$ & $(1.70)$ & $(2.71)$ & \\
\hline 45 vs 50 Hours & $\$ 22.69$ & $\$ 19.97$ & $\$ 10.59$ & $\$ 22.69$ & $\$ 34.80$ & 129 \\
\hline & $(1.54)$ & (1.35) & $(0.72)$ & $(1.54)$ & $(2.36)$ & \\
\hline Implied $\tilde{z}$ & 0.58 & & & 0.58 & & 902 \\
\hline & $(0.04)$ & & & (0.04) & & \\
\hline
\end{tabular}

Notes: This table replicates Table 3, where the data are not corrected for inattention. 
Appendix Table 5. Marginal Value of Time

All Experiment Applicants

\begin{tabular}{|c|c|c|c|c|c|c|}
\hline & \multirow[b]{2}{*}{ Mean } & \multicolumn{5}{|c|}{ Quantiles } \\
\hline & & $\begin{array}{l}\text { Standard } \\
\text { Deviation }\end{array}$ & 25 th & 50th & 75th & $\mathrm{N}$ \\
\hline \multirow[t]{2}{*}{5 vs. 10 Hours } & $\$ 5.37$ & $\$ 8.37$ & $\$ 0.30$ & $\$ 5.37$ & $\$ 10.44$ & 304 \\
\hline & $(0.78)$ & (1.53) & $(1.23)$ & $(0.78)$ & $(1.20)$ & \\
\hline \multirow[t]{2}{*}{10 vs. 15 Hours } & $\$ 6.58$ & $\$ 10.87$ & $-\$ 0.01$ & $\$ 6.58$ & $\$ 13.16$ & 305 \\
\hline & $(1.03)$ & (1.64) & $(1.64)$ & $(1.03)$ & (1.19) & \\
\hline \multirow[t]{2}{*}{15 vs. 20 Hours } & $\$ 8.56$ & $\$ 11.12$ & $\$ 1.82$ & $\$ 8.56$ & $\$ 15.30$ & 323 \\
\hline & $(0.97)$ & (1.79) & $(1.59)$ & (0.97) & $(1.30)$ & \\
\hline \multirow[t]{2}{*}{20 vs. 25 Hours } & $\$ 9.88$ & $\$ 13.00$ & $\$ 2.01$ & $\$ 9.88$ & $\$ 17.76$ & 292 \\
\hline & $(1.15)$ & $(2.01)$ & $(1.81)$ & $(1.15)$ & $(1.51)$ & \\
\hline \multirow[t]{2}{*}{25 vs. 30 Hours } & $\$ 11.23$ & $\$ 14.00$ & $\$ 2.75$ & $\$ 11.23$ & $\$ 19.71$ & 305 \\
\hline & $(1.21)$ & $(2.12)$ & $(2.01)$ & $(1.21)$ & $(1.48)$ & \\
\hline \multirow[t]{2}{*}{30 vs. 35 Hours } & $\$ 16.40$ & $\$ 9.79$ & $\$ 10.47$ & $\$ 16.40$ & $\$ 22.33$ & 319 \\
\hline & $(0.89)$ & $(1.51)$ & $(1.36)$ & $(0.89)$ & $(1.18)$ & \\
\hline \multirow[t]{2}{*}{35 vs. 40 Hours } & $\$ 13.21$ & $\$ 13.85$ & $\$ 4.82$ & $\$ 13.21$ & $\$ 21.60$ & 272 \\
\hline & $(1.22)$ & $(2.41)$ & $(1.97)$ & $(1.22)$ & $(1.84)$ & \\
\hline \multirow[t]{2}{*}{40 vs. 45 Hours } & $\$ 21.19$ & $\$ 16.15$ & $\$ 11.41$ & $\$ 21.19$ & $\$ 30.98$ & 272 \\
\hline & $(1.03)$ & $(0.78)$ & $(0.55)$ & $(1.03)$ & $(1.51)$ & \\
\hline \multirow[t]{2}{*}{45 vs. 50 Hours } & $\$ 25.50$ & $\$ 16.85$ & $\$ 15.29$ & $\$ 25.50$ & $\$ 35.71$ & 266 \\
\hline & $(1.13)$ & $(0.74)$ & $(0.67)$ & $(1.13)$ & $(1.58)$ & \\
\hline \multirow{2}{*}{ Implied $\tilde{z}$} & 0.63 & & & 0.63 & & 2,120 \\
\hline & $(0.03)$ & & & $(0.03)$ & & \\
\hline
\end{tabular}

Notes: This table replicates Table 3, where all experiment applicants are included regardless of employment status. 
Appendix Table 6. Marginal Value of Time

Unemployed Applicants who Completed the Application

\begin{tabular}{|c|c|c|c|c|c|c|}
\hline & \multirow[b]{2}{*}{ Mean } & \multicolumn{5}{|c|}{ Quantiles } \\
\hline & & $\begin{array}{l}\text { Standard } \\
\text { Deviation }\end{array}$ & 25th & 50th & 75th & $\mathrm{N}$ \\
\hline \multirow[t]{2}{*}{5 vs. 10 Hours } & $\$ 4.53$ & $\$ 5.72$ & $\$ 1.07$ & $\$ 4.53$ & $\$ 8.00$ & 113 \\
\hline & $(0.99)$ & (1.39) & $(1.29)$ & $(0.99)$ & $(1.31)$ & \\
\hline \multirow[t]{2}{*}{10 vs. 15 Hours } & $\$ 5.25$ & $\$ 6.48$ & $\$ 1.32$ & $\$ 5.25$ & $\$ 9.18$ & 123 \\
\hline & $(1.06)$ & $(1.61)$ & $(1.51)$ & $(1.06)$ & $(1.37)$ & \\
\hline \multirow[t]{2}{*}{15 vs. 20 Hours } & $\$ 7.03$ & $\$ 12.64$ & $-\$ 0.62$ & $\$ 7.03$ & $\$ 14.69$ & 128 \\
\hline & (1.77) & $(3.52)$ & $(3.24)$ & $(1.77)$ & $(2.21)$ & \\
\hline \multirow[t]{2}{*}{20 vs. 25 Hours } & $\$ 8.72$ & $\$ 14.63$ & $-\$ 0.14$ & $\$ 8.72$ & $\$ 17.59$ & 150 \\
\hline & $(1.75)$ & $(3.43)$ & $(2.96)$ & $(1.75)$ & $(2.45)$ & \\
\hline \multirow[t]{2}{*}{25 vs. 30 Hours } & $\$ 7.98$ & $\$ 13.19$ & $-\$ 0.01$ & $\$ 7.98$ & $\$ 15.97$ & 131 \\
\hline & $(1.92)$ & $(2.95)$ & $(3.11)$ & $(1.92)$ & $(2.02)$ & \\
\hline \multirow[t]{2}{*}{30 vs. 35 Hours } & $\$ 14.64$ & $\$ 9.77$ & $\$ 8.72$ & $\$ 14.64$ & $\$ 20.56$ & 131 \\
\hline & $(1.43)$ & (1.88) & $(1.73)$ & $(1.43)$ & $(1.92)$ & \\
\hline \multirow[t]{2}{*}{35 vs. 40 Hours } & $\$ 11.99$ & $\$ 9.57$ & $\$ 6.19$ & $\$ 11.99$ & $\$ 17.79$ & 112 \\
\hline & $(1.53)$ & (2.29) & $(2.23)$ & (1.53) & $(1.88)$ & \\
\hline \multirow[t]{2}{*}{40 vs. 45 Hours } & $\$ 21.25$ & $\$ 18.08$ & $\$ 10.29$ & $\$ 21.25$ & $\$ 32.20$ & 118 \\
\hline & $(1.71)$ & $(1.46)$ & $(0.83)$ & $(1.71)$ & $(2.60)$ & \\
\hline \multirow[t]{2}{*}{45 vs. 50 Hours } & $\$ 22.60$ & $\$ 17.34$ & $\$ 12.09$ & $\$ 22.60$ & $\$ 33.11$ & 128 \\
\hline & $(1.55)$ & (1.19) & $(0.83)$ & $(1.55)$ & $(2.27)$ & \\
\hline \multirow[t]{2}{*}{ Implied $\tilde{z}$} & 0.57 & & & 0.57 & & 888 \\
\hline & $(0.04)$ & & & $(0.04)$ & & \\
\hline
\end{tabular}

Notes: This table replicates Table 3, where only unemployed applicants who finished the application are included. 


\begin{tabular}{|c|c|c|c|c|c|c|c|c|c|}
\hline & \multirow[b]{2}{*}{ All } & \multicolumn{2}{|c|}{ Employment Status } & \multicolumn{2}{|c|}{ Gender } & \multicolumn{2}{|c|}{ Weighting Scheme } & \multicolumn{2}{|c|}{ UI Eligibility } \\
\hline & & Unemployed & Employed & Women & Men & $\begin{array}{c}\text { Pre-Experiment } \\
\text { Characteristics }\end{array}$ & $\begin{array}{c}\text { All } \\
\text { Characteristics }\end{array}$ & $\begin{array}{c}\text { Eligible for } \\
\text { Benefits }\end{array}$ & $\begin{array}{c}\text { Ineligible for } \\
\text { Benefits }\end{array}$ \\
\hline Predicted Wage & $\$ 14.86$ & $\$ 13.93$ & $\$ 16.14$ & $\$ 14.42$ & $\$ 16.75$ & $\$ 15.55$ & $\$ 15.01$ & $\$ 13.68$ & $\$ 14.53$ \\
\hline Observations & 2,120 & 902 & 660 & 1,494 & 315 & 726 & 726 & 644 & 251 \\
\hline
\end{tabular}

Notes: Predicted wages are created as described in the text. The "Weighting Scheme" and "UI Eligibility" columns are limited to unemployed applicants. Applicants are categorized as eligible or ineligible for UI based only on state and unemployment duration as described in the text. 
Appendix Table 8. Overtime Marginal Value of Time: Robustness to Constraints

Unemployed Applicants

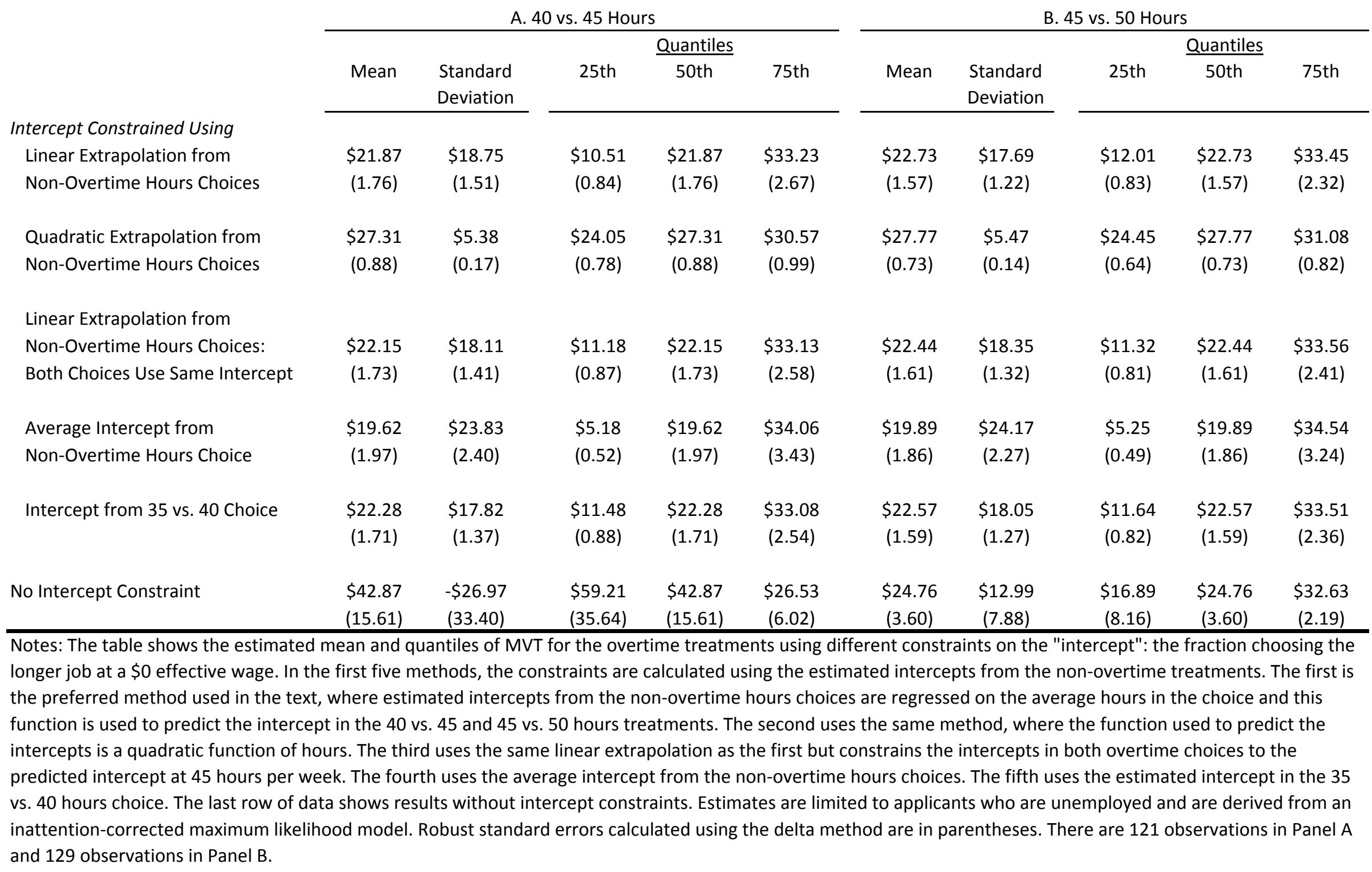


Appendix Table 9. Descriptive Statistics using Sample Weights

Unemployed Applicants

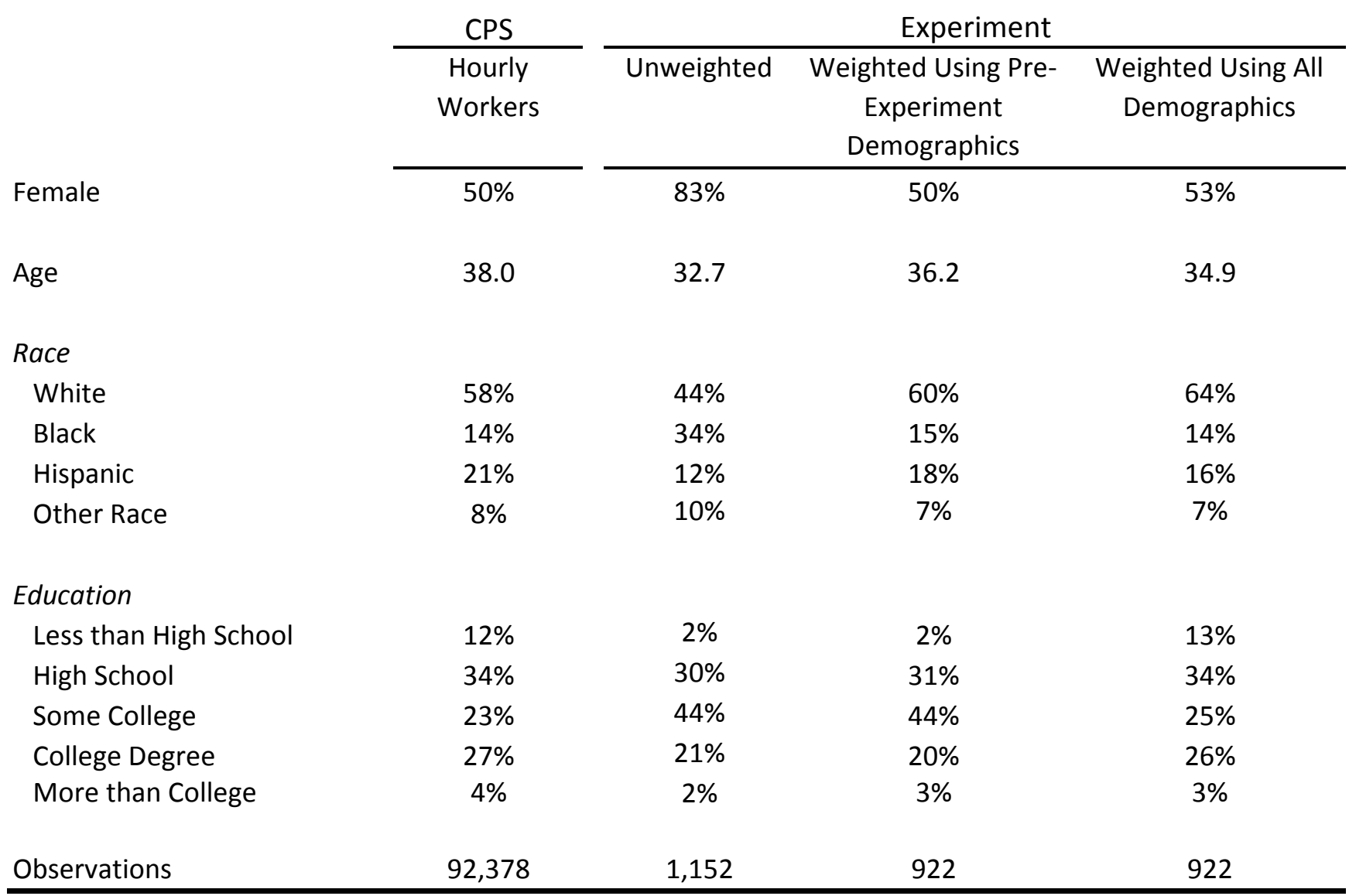

Notes: The first column of data shows descriptive statistics for hourly workers ages 16-64 in the 2016 CPS

Merged Outgoing Rotation Groups. The second, third, and fourth columns of data show descriptive characteristics for unemployed applicants in our experiment, with different weights. Pre-experiment demographics are collected before the job options are presented. These weights are constructed using race categories, a female dummy, age, and age*race, age*female, and female*race interaction terms. The weights in the final column are generated using these characteristics and educational attainment categories. Sample weights are capped at a maximum of 10 standard deviations above the sample mean weight. This restriction affects 1 observation in the third column of data and 5 in the fourth. 
Appendix Table 10. Labor Supply Elasticities

All Experiment Applicants

\begin{tabular}{|c|c|c|c|c|}
\hline & Raw Points & Quadratic & Quartic & Spline \\
\hline 10 Hours & 2.46 & 4.34 & 2.57 & 1.67 \\
\hline 15 Hours & 1.27 & 2.03 & 1.39 & 1.45 \\
\hline 20 Hours & 1.74 & 1.31 & 1.23 & 1.34 \\
\hline 25 Hours & 1.57 & 1.00 & 1.25 & 1.27 \\
\hline 30 Hours & 0.45 & 0.83 & 1.19 & 1.22 \\
\hline 35 Hours & -0.66 & 0.74 & 0.93 & 1.19 \\
\hline 40 Hours & 0.27 & 0.68 & 0.62 & 0.54 \\
\hline 45 Hours & 0.60 & 0.64 & 0.42 & 0.40 \\
\hline RMSE & & 1.96 & 2.13 & 1.63 \\
\hline
\end{tabular}

Notes: This table replicates Table 5, where the sample is not limited to unemployed applicants. 
Appendix Table 11. Marginal Value of Time by Gender All Experiment Applicants

\begin{tabular}{|c|c|c|c|c|c|c|c|c|c|c|c|c|}
\hline & \multicolumn{6}{|c|}{ A. Women } & \multicolumn{6}{|c|}{ B. Men } \\
\hline & \multicolumn{6}{|c|}{$\overline{\text { Quantiles }}$} & \multicolumn{6}{|c|}{ Quantiles } \\
\hline & Mean & $\begin{array}{l}\text { Standard } \\
\text { Deviation }\end{array}$ & 25 th & 50th & 75th & $\mathrm{N}$ & Mean & $\begin{array}{l}\text { Standard } \\
\text { Deviation }\end{array}$ & 25th & 50th & 75th & $\mathrm{N}$ \\
\hline 5 vs 10 Hours & $\begin{array}{l}\$ 5.03 \\
(1.11)\end{array}$ & $\begin{array}{l}\$ 9.93 \\
(1.81)\end{array}$ & $\begin{array}{l}-\$ 0.99 \\
(1.76)\end{array}$ & $\begin{array}{l}\$ 5.03 \\
(1.11)\end{array}$ & $\begin{array}{l}\$ 11.05 \\
(1.33)\end{array}$ & 226 & $\begin{array}{l}\$ 5.43 \\
(1.19)\end{array}$ & $\begin{array}{l}\$ 3.23 \\
(1.26)\end{array}$ & $\begin{array}{l}\$ 3.48 \\
(1.38)\end{array}$ & $\begin{array}{l}\$ 5.43 \\
(1.19)\end{array}$ & $\begin{array}{l}\$ 7.39 \\
(1.44)\end{array}$ & 38 \\
\hline 10 vs 15 Hours & $\begin{array}{l}\$ 6.25 \\
(1.36)\end{array}$ & $\begin{array}{l}\$ 11.47 \\
(2.14)\end{array}$ & $\begin{array}{l}-\$ 0.70 \\
(2.23)\end{array}$ & $\begin{array}{l}\$ 6.25 \\
(1.36)\end{array}$ & $\begin{array}{l}\$ 13.20 \\
(1.45)\end{array}$ & 208 & $\begin{array}{l}\$ 8.49 \\
(1.85)\end{array}$ & $\begin{array}{l}\$ 6.64 \\
(2.42)\end{array}$ & $\begin{array}{l}\$ 4.47 \\
(2.35)\end{array}$ & $\begin{array}{l}\$ 8.49 \\
(1.85)\end{array}$ & $\begin{array}{l}\$ 12.51 \\
(2.36)\end{array}$ & 43 \\
\hline 15 vs 20 Hours & $\begin{array}{l}\$ 7.78 \\
(1.21)\end{array}$ & $\begin{array}{c}\$ 11.33 \\
(2.14)\end{array}$ & $\begin{array}{l}\$ 0.92 \\
(2.07)\end{array}$ & $\begin{array}{l}\$ 7.78 \\
(1.21)\end{array}$ & $\begin{array}{l}\$ 14.65 \\
(1.42)\end{array}$ & 241 & $\begin{array}{l}\$ 9.65 \\
(3.05)\end{array}$ & $\begin{array}{l}\$ 15.16 \\
(8.18)\end{array}$ & $\begin{array}{l}\$ 0.46 \\
(5.49)\end{array}$ & $\begin{array}{l}\$ 9.65 \\
(3.05)\end{array}$ & $\begin{array}{c}\$ 18.83 \\
(6.14)\end{array}$ & 46 \\
\hline 20 vs 25 Hours & $\begin{array}{l}\$ 9.81 \\
(1.25)\end{array}$ & $\begin{array}{l}\$ 11.11 \\
(1.88)\end{array}$ & $\begin{array}{l}\$ 3.08 \\
(1.78)\end{array}$ & $\begin{array}{l}\$ 9.81 \\
(1.25)\end{array}$ & $\begin{array}{l}\$ 16.54 \\
(1.60)\end{array}$ & 194 & $\begin{array}{c}\$ 13.29 \\
(3.76)\end{array}$ & $\begin{array}{l}\$ 21.31 \\
(10.12)\end{array}$ & $\begin{array}{l}\$ 0.38 \\
(7.01)\end{array}$ & $\begin{array}{l}\$ 13.29 \\
(3.76)\end{array}$ & $\begin{array}{l}\$ 26.20 \\
(7.38)\end{array}$ & 56 \\
\hline 25 vs 30 Hours & $\begin{array}{c}\$ 11.83 \\
(1.32)\end{array}$ & $\begin{array}{l}\$ 12.51 \\
(2.06)\end{array}$ & $\begin{array}{l}\$ 4.25 \\
(2.06)\end{array}$ & $\begin{array}{c}\$ 11.83 \\
(1.32)\end{array}$ & $\begin{array}{l}\$ 19.41 \\
(1.54)\end{array}$ & 211 & $\begin{array}{l}\$ 13.73 \\
(3.15)\end{array}$ & $\begin{array}{l}\$ 14.84 \\
(6.26)\end{array}$ & $\begin{array}{l}\$ 4.74 \\
(4.42)\end{array}$ & $\begin{array}{l}\$ 13.73 \\
(3.15)\end{array}$ & $\begin{array}{l}\$ 22.73 \\
(5.40)\end{array}$ & 45 \\
\hline 30 vs 35 Hours & $\begin{array}{c}\$ 16.37 \\
(1.13)\end{array}$ & $\begin{array}{l}\$ 10.35 \\
(1.90)\end{array}$ & $\begin{array}{l}\$ 10.10 \\
(1.76)\end{array}$ & $\begin{array}{c}\$ 16.37 \\
(1.13)\end{array}$ & $\begin{array}{l}\$ 22.64 \\
(1.45)\end{array}$ & 222 & $\begin{array}{c}\$ 15.73 \\
(1.19)\end{array}$ & $\begin{array}{l}\$ 3.96 \\
(1.73)\end{array}$ & $\begin{array}{l}\$ 13.33 \\
(1.73)\end{array}$ & $\begin{array}{l}\$ 15.73 \\
(1.19)\end{array}$ & $\begin{array}{l}\$ 18.14 \\
(1.43)\end{array}$ & 51 \\
\hline 35 vs 40 Hours & $\begin{array}{c}\$ 13.11 \\
(1.57)\end{array}$ & $\begin{array}{l}\$ 15.30 \\
(3.21)\end{array}$ & $\begin{array}{l}\$ 3.84 \\
(2.59)\end{array}$ & $\begin{array}{c}\$ 13.11 \\
(1.57)\end{array}$ & $\begin{array}{l}\$ 22.38 \\
(2.41)\end{array}$ & 192 & $\begin{array}{c}\$ 10.66 \\
(3.06)\end{array}$ & $\begin{array}{l}\$ 11.41 \\
(4.85)\end{array}$ & $\begin{array}{l}\$ 3.75 \\
(5.02)\end{array}$ & $\begin{array}{l}\$ 10.66 \\
(3.06)\end{array}$ & $\begin{array}{c}\$ 17.58 \\
(3.27)\end{array}$ & 36 \\
\hline 40 vs 45 Hours & $\begin{array}{c}\$ 21.98 \\
(1.17)\end{array}$ & $\begin{array}{l}\$ 15.41 \\
(0.82)\end{array}$ & $\begin{array}{l}\$ 12.65 \\
(0.67)\end{array}$ & $\begin{array}{c}\$ 21.98 \\
(1.17)\end{array}$ & $\begin{array}{l}\$ 31.32 \\
(1.67)\end{array}$ & 203 & $\begin{array}{c}\$ 14.71 \\
(2.86)\end{array}$ & $\begin{array}{l}\$ 14.91 \\
(2.90)\end{array}$ & $\begin{array}{l}\$ 5.67 \\
(1.10)\end{array}$ & $\begin{array}{l}\$ 14.71 \\
(2.86)\end{array}$ & $\begin{array}{l}\$ 23.74 \\
(4.62)\end{array}$ & 31 \\
\hline 45 vs 50 Hours & $\begin{array}{c}\$ 26.75 \\
(1.31)\end{array}$ & $\begin{array}{l}\$ 15.27 \\
(0.75)\end{array}$ & $\begin{array}{l}\$ 17.50 \\
(0.86)\end{array}$ & $\begin{array}{c}\$ 26.75 \\
(1.31)\end{array}$ & $\begin{array}{c}\$ 36.01 \\
(1.76)\end{array}$ & 177 & $\begin{array}{c}\$ 20.01 \\
(3.01)\end{array}$ & $\begin{array}{l}\$ 20.51 \\
(3.09)\end{array}$ & $\begin{array}{l}\$ 7.58 \\
(1.14)\end{array}$ & $\begin{array}{l}\$ 20.01 \\
(3.01)\end{array}$ & $\begin{array}{c}\$ 32.44 \\
(4.89)\end{array}$ & 38 \\
\hline Implied $\tilde{z}$ & $\begin{array}{c}0.64 \\
(0.04)\end{array}$ & & & $\begin{array}{c}0.64 \\
(0.04)\end{array}$ & & 1,494 & $\begin{array}{c}0.59 \\
(0.06)\end{array}$ & & & $\begin{array}{c}0.59 \\
(0.06)\end{array}$ & & 315 \\
\hline
\end{tabular}

Notes: This table replicates Table 3, where applicants are included regardless of their employment status and results are shown separately by gender. 